\title{
Lower Kimmeridgian facies and sedimentary succession of a shallow-water coated-grain-dominated carbonate ramp of the northern peri-Tethyan shelf: an example from the Radomsko Folds (central Poland)
}

\author{
Piotr OLCHOWY ${ }^{1, *}$ and Marcin KRAJEWSKI ${ }^{1}$
}

1 AGH University of Science and Technology, Faculty of Geology, Geophysics and Environmental Protection, al. A. Mickiewicza 30, 30-059 Kraków, Poland

Olchowy, P., Krajewski, M., 2020. Lower Kimmeridgian facies and sedimentary succession of a shallow-water coated-grain-dominated carbonate ramp of the northern peri-Tethyan shelf: an example from the Radomsko Folds (central Poland). Geological Quarterly, 64 (4): 969-987, doi: 10.7306/gq.1563

An Upper Jurassic succession is exposed in the active Rogaszyn Quarry (Kodrąb area) located in the Radomsko Folds structure (central Poland). Six facies types were distinguished, comprising oolitic, oncolitic, biodetrital and pelitic limestones as well as marls and marly clays. Typical lithologies are limestones with coated grains deposited in shallow-water, fore-shoal, shoal and lagoonal parts of a carbonate ramp. Three types of ooid and three types of oncoid were identified, which display several shapes and sizes, and a complex structure of cortices. The ooid types show micritic, radial-fibrous and mixed, micritic/radial-fibrous cortices. Type 1 oncoids comprise micritic or bioclastic nuclei enveloped by non-laminated or laminated micritic cortices. Type 2 oncoids are composed of micritic or bioclastic nuclei and laminated, fossil-bearing cortices covered by microbial envelopes. Type 3 oncoids are the largest of the oncoids observed, attaining cm-scale dimensions. These oncoids are formed of a Bacinella-dominated meshwork incorporating smaller ooids and oncoids, or they have bioclastic or micritic nuclei covered by complex cortices with micritic, laminated, fossil-bearing, Bacinella-dominated fabric and microbial envelopes. Boundaries between the specific types of cortical envelopes are usually sharp and accentuated by organic encrustations, elongated bioclasts or borings. Commonly found are chambers of the ichnogenus Entobia representing the boring traces of carbonate-excavating sponges and the cryptoendolithic foraminifer Troglotella incrustants. The complex cortices indicate different growth stages of oncoids at different conditions of currents and microbial activity. Carbonate deposition was accompanied by mixed siliciclastic-carbonate sedimentation resulting in multiple intercalated layers of marls and pelitic limestones as well as marly clays. The deposits exposed in the Rogaszyn Quarry as well as in the Kodrab area are compared with the neighbouring Upper Jurassic deposits of the Szczerców area and the SW margin of the Holy Cross Mts. (both central Poland). The successions from the Kodrąb area are generally similar to the Lower Kimmeridgian sequences known from adjacent areas, but with locally observed facies variability.

Key words: Late Jurassic, carbonate ramp, Kimmeridgian, oncoids, lithofacies.

\section{INTRODUCTION}

During the Late Jurassic, central Poland was an epicontinental sea that bordered the northern margin of the Tethys Ocean (e.g., Ziegler, 1990; Matyszkiewicz, 1997). The Oxfordian and the Lower Kimmeridgian succession of central Poland was included by Kutek (1994) in a "COK sequence" (COK = Callovian-Oxfordian-Lower Kimmeridgian). This sequence comprises two intervals - I and II, separated by an isochronous marker horizon termed the "Lowermost Marly Horizon", which is one of the most important Lower Kimmeridgian markers in central Poland (e.g., Kutek, 1968, 1994; Matyja, 2011; Krajewski et al., 2014, 2017; Olchowy et al., 2019; Słonka and Krzywiec, 2020a, b). Interval I includes Oxfordian and Lower Kimmeridgian deposits (up to the Planula Zone), which

\footnotetext{
* Corresponding author, e-mail: piotr.olchowy@agh.edu.pl
} Received: March 24, 2020; accepted: September 9, 2020; first published online: Ocober 27, 2020 are developed in central and southern Poland mostly as limestones rich in benthic fauna, mainly siliceous and calcareous sponges (including chaetetids), as well as corals and various microbialites (see e.g., Roniewicz and Roniewicz, 1971; Matyja et al., 1989; Trammer, 1989; Matyszkiewicz et al., 2012; Matyszkiewicz and Kochman, 2016; Krajewski et al., 2018; Olchowy et al., 2019; Słonka and Krzywiec, 2020a, b), whereas marls and marly limestones are in minor proportion. In Interval II (Platynota and Hypselocyclum zones), marls and marly limestones prevail along with limestones with numerous coated grains, usually ooids and oncoids (e.g., Kutek and Radwański, 1965, 1967; Kutek, 1968; Matyja, 2011; Olchowy et al., 2019). The benthic fauna observed in the Interval II deposits is dominated by bivalves, echinoids, crinoids and gastropods, whereas sponges and corals are less common. Hardgrounds are frequent (e.g., Kaźmierczak and Pszczółkowski, 1968; Goldring and Kaźmierczak, 1974; Chudzikiewicz and Wieczorek, 1985; Gruszczyński, 1986; Krajewski et al., 2014, 2017; Olchowy et al., 2019), some of them suitable for regional correlation.

In the Radomsko Folds area, one of the best examples of a Kimmeridgian sedimentary succession can be observed in 


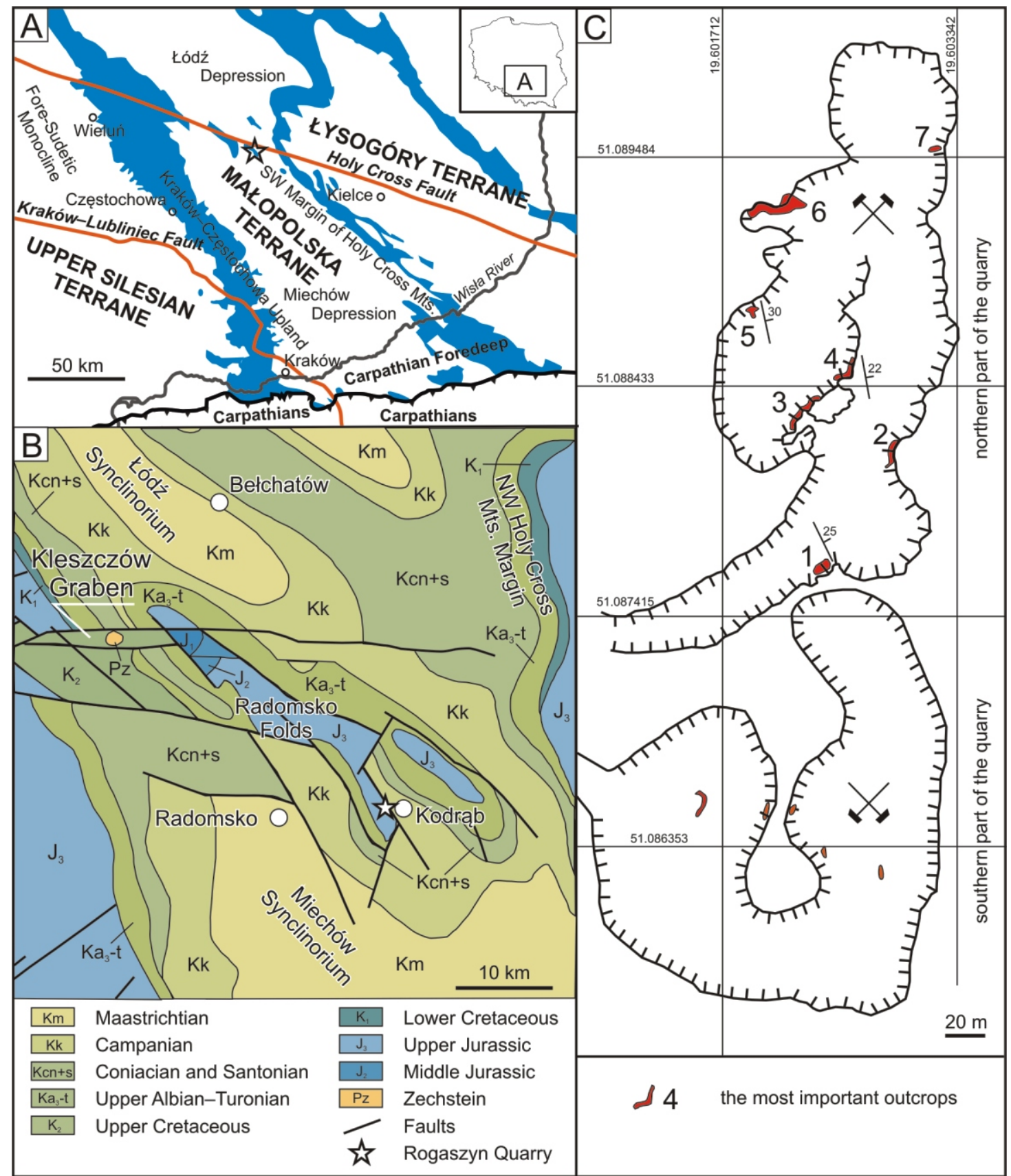

Fig. 1. Location maps of the study area

A - study area showing the Upper Jurassic outcrops and sub-Cenozoic Jurassic subcrops (blue) in southern and central Poland (modified from Pożaryski et al., 1979), tectonic structures (red) after Żelaźniewicz et al. (2011); B - geological map (after Dadlez et al., 2000) with position of Rogaszyn Quarry and the Radomsko Folds; C - sketch-map of the northern and southern parts of Rogaszyn Quarry with locations of the most important exposures

Rogaszyn Quarry (Kodrąb area, Smotryszów Anticline), where the upper part of the "COK sequence" is developed. Taking into account the location of that quarry between the areas of the Wieluń Upland, the SW margin of the Holy Cross Mts. as well as the Łódź, Miechów and Tomaszów depressions (Fig. 1A, B), the Rogaszyn Quarry succession is of key importance for correlation of the Upper Jurassic strata of central Poland.

The Lower Kimmeridgian deposits in Rogaszyn Quarry (Smotryszów Anticline) were recently the subject of controversy concerning the sedimentary succession and its correlation with the neighbouring areas (Wierzbowski and Głowniak, 2018, 2019; Olchowy and Krajewski, 2019). Here, we provide documentation of the Rogaszyn Quarry succession (Figs. 2-11) with identification of a number of facies and microfacies containing various coated grains. Moreover, lithostratigraphic correlations are made of the Lower Kimmeridgian succession in the Radomsko Folds area with those at the border of the Łódź and Miechów depressions (Szczerców area) and the SW margin of the Holy Cross Mts. 


\section{GEOLOGICAL SETTING AND STATE OF KNOWLEDGE OF KIMMERIDGIAN DEPOSITS IN THE SMOTRYSZÓW ANTICLINE}

The study area is located in central Poland, $\sim 2 \mathrm{~km}$ southwest of Kodrąb village, within the Radomsko Folds structure (Żelaźniewicz et al., 2011; Fig. 1B, C), which is also known as the "Radomsko Elevation" in the older literature (Pożaryski, 1974). This structure is a part of the Szczecin-Miechów Synclinorium, in which it separates the Mogilno-Łódź and the Miechów segments. The Radomsko Folds include numerous NW-SE-trending anticlines and synclines (e.g., the Łękińsko, Smotryszów and Chełm anticlines). The development of the Radomsko Folds is related to NW-SE-directed stretching of the Holy Cross Mts. Fault during the Laramide tectonic movements. This fault is interpreted as the northern margin of the Małopolska Block, which, in turn, forms the periphery of the West European Platform (e.g., Żelaźniewicz et al., 2011).

In the study area, Upper Jurassic deposits have been described mostly from the Smotryszów Anticline, outcropping on the SW and the NE limbs of that anticline. The SW zone is named as the Dmenin Ridge, whereas that on the NE is the Smotryszów Ridge (e.g., Łuniewski, 1947; Kutek, 1968). On the Smotryszów Ridge, Upper Jurassic deposits have been reported from many quarries, particularly the Smotryszów and the Rogaszyn quarries (e.g., Łuniewski, 1947; Jaworowski, 1962 Karczewski, 1965; Kutek, 1968; Wierzbowski and Głowniak, 2018). According to Jaworowski (1962), the Upper Jurassic sedimentary succession of the Smotryszów Anticline includes pelitic limestones with bivalves and corals, grading upwards into oolitic, pelitic and oncolitic limestones.

\section{LITHOSTRATIGRAPHY OF THE UPPER JURASSIC DEPOSITS} IN THE KODRAB AREA BASED ON DATA FROM EXPOSURES

In Smotryszów Quarry (situated in the NE margin of the Smotryszów Anticline), Kutek (1968) distinguished the so-called "Chalky Limestone member" (Planula and Platynota zones, dated by ammonites) with corals, solenopores, nerineid gastropods and diceratid bivalves, and with thin intercalations of pelitic and oolitic limestones. These deposits are $\sim 50 \mathrm{~m}$ thick on Smotryszów Ridge, whereas in Smotryszów Quarry, only the uppermost part was exposed (nowadays completely covered by dense vegetation), up to several metres thick. Above the "Chalky Limestone member", Kutek (1968) described the "Platy-Onkolite member", 10 m thick, composed mostly of limestones with numerous oncoids (macro-oncoids sensu Kutek and Radwański, 1965). Finally, the upper part of the Smotryszów Quarry succession comprises marly shales and pelitic platy limestones. In describing the Upper Jurassic succession in Smotryszów Quarry and numbering its particular beds, Kutek (1968: 527 and fig. 13 therein) suggested that it extends as far as Rogaszyn Quarry, $\sim 2.5 \mathrm{~km}$ distant. In Rogaszyn Quarry, the Lower Kimmeridgian succession reaches $\sim 11 \mathrm{~m}$ thick, in which Kutek (1968: 527) identified the "Platy-Onkolite member", composed of marly shales grading upwards into intercalated pelitic platy limestones, oncolitic limestones and marly shales. The total thickness of this member in the Smotryszów Anticline is $230 \mathrm{~m}$ (Kutek, 1968: 526). Up-sequence of the Smotryszów Ridge, Kutek (1968: 520) proposed the presence of the "Oolite of Smotryszów", consisting of an oolitic limestone (Hypselocyclum Zone) of undefined (but at least $10 \mathrm{~m}$ ) total thickness. This author reported the occurrence of these deposits in small quarries located to the east of Rogaszyn Quarry, although detailed documentation was not provided.
On Dmenin Ridge (at the SW margin of the Smotryszów Anticline), Kutek (1968; see also Jaworowski, 1962) identified the oldest Upper Jurassic strata as the "Oncolites of Dmenin", consisting of oncolitic limestones at least $10 \mathrm{~m}$ thick. These deposits are overlain by the "Platy Limestones" and the "Underlying Clays of Dmenin", $~ 50$ m thick, developed as shaly marls with intercalations of limestone and marl, grading up-sequence into $10 \mathrm{~m}$ thick pelitic platy limestones. The uppermost Jurassic deposits on the Dmenin Ridge were named by Kutek (1968) as the "Top Clays of Dmenin", which comprise marly shales $60 \mathrm{~m}$ thick with intercalations of limestone and marl and Exogyra coquinas.

In the last few years, the Lower Kimmeridgian sedimentary succession of the Smotryszów Anticline has also been interpreted by Wierzbowski and Głowniak (2018; cf. Olchowy and Krajewski, 2019; Wierzbowski and Głowniak, 2019).

LITHOSTRATIGRAPHY OF THE UPPER JURASSIC DEPOSITS OF THE KODRĄB AREA BASED ON DATA FROM BOREHOLES

The most complete Lower Kimmeridgian succession of the Smotryszów Anticline was described by Barwicz-Piskorz (1992, 1995), encompassing strata outcropping on both the Smotryszów and Dmenin ridges. A comprehensive lithological log was constructed from the fully cored boreholes drilled for the geological assessment project of the Rogaszyn limestone deposit. This author described $\sim 325 \mathrm{~m}$ of Upper Jurassic strata subdivided into many characteristic and regional lithostratigraphic units previously distinguished by Kutek (1968) and Dembowska (1979). Moreover, Barwicz-Piskorz (1992, 1995) correlated the Upper Jurassic deposits of the Smotryszów Anticline with those of the Kleszczów area (Łękińsko Anticline) and the Granice area (Chełmno Anticline), both also located within the Radomsko Folds structure.

According to Barwicz-Piskorz (1992, 1995), the oldest Upper Jurassic deposit in the Kodrąb area is the bedded "Chalky Limestone", 10 m thick, showing abundant gastropods, bivalves, echinoderms and corals, and with locally observed cherts (Fig. 12B). This interval is followed by $\sim 25 \mathrm{~m}$ of grey marly limestones and marls. Up-sequence, deposits similar to the "Chalky Limestone" appear ( $60 \mathrm{~m}$ thick), overlain by up to $33 \mathrm{~m}$ of thin- and medium-bedded pelitic limestones with rare bivalves, intercalated with detrital limestones and thin marly beds. These deposits are overlain by $6 \mathrm{~m}$ of marls and marly limestones, usually devoid of fossils, named by BarwiczPiskorz (1992, 1995) as the "Lowermost Marly Horizon" (Fig. 12B). This unit is overlain by $50 \mathrm{~m}$ of oolitic-biodetrital limestones with bivalves, gastropods, individual corals and oncoids in the upper part. The top surface of this unit is a hardground with washouts and borings (see Barwicz-Piskorz, 1995; Fig. 5), overlain, in turn, by up to $2 \mathrm{~m}$ of oncolitic limestones with numerous oval oncoids with bivalve shells as nuclei. Up-sequence, the oncolitic limestones grade into marly limestones and oncolitic limestones. The total thickness of these last three units reaches up to $\sim 12 \mathrm{~m}$ (Fig. 12B). The next part of the sequence comprises some-metres-thick marls grading into bioclasticpelitic limestones with bivalves (e.g., Nanogyra and pectinids) and scarce ooids, overlain by marly limestones with marl interbeds and a hardground. These deposits are followed by $14 \mathrm{~m}$ of platy pelitic and marly limestones with numerous oysters and marl intercalations. Up-sequence, marls with abundant Lopha bivalves and rare ooids occur, $\sim 10 \mathrm{~m}$ thick, overlain by a succession of marls and oyster coquinas (composed of mass accumulations of Nanogyra virgula and Nanogyra nana) $\sim 64 \mathrm{~m}$ thick, locally intercalated with marly-biodetrital limestones. The uppermost part of the sequence includes marly clays and platy marls, $\sim 6 \mathrm{~m}$ thick (Barwicz-Piskorz, 1995). 

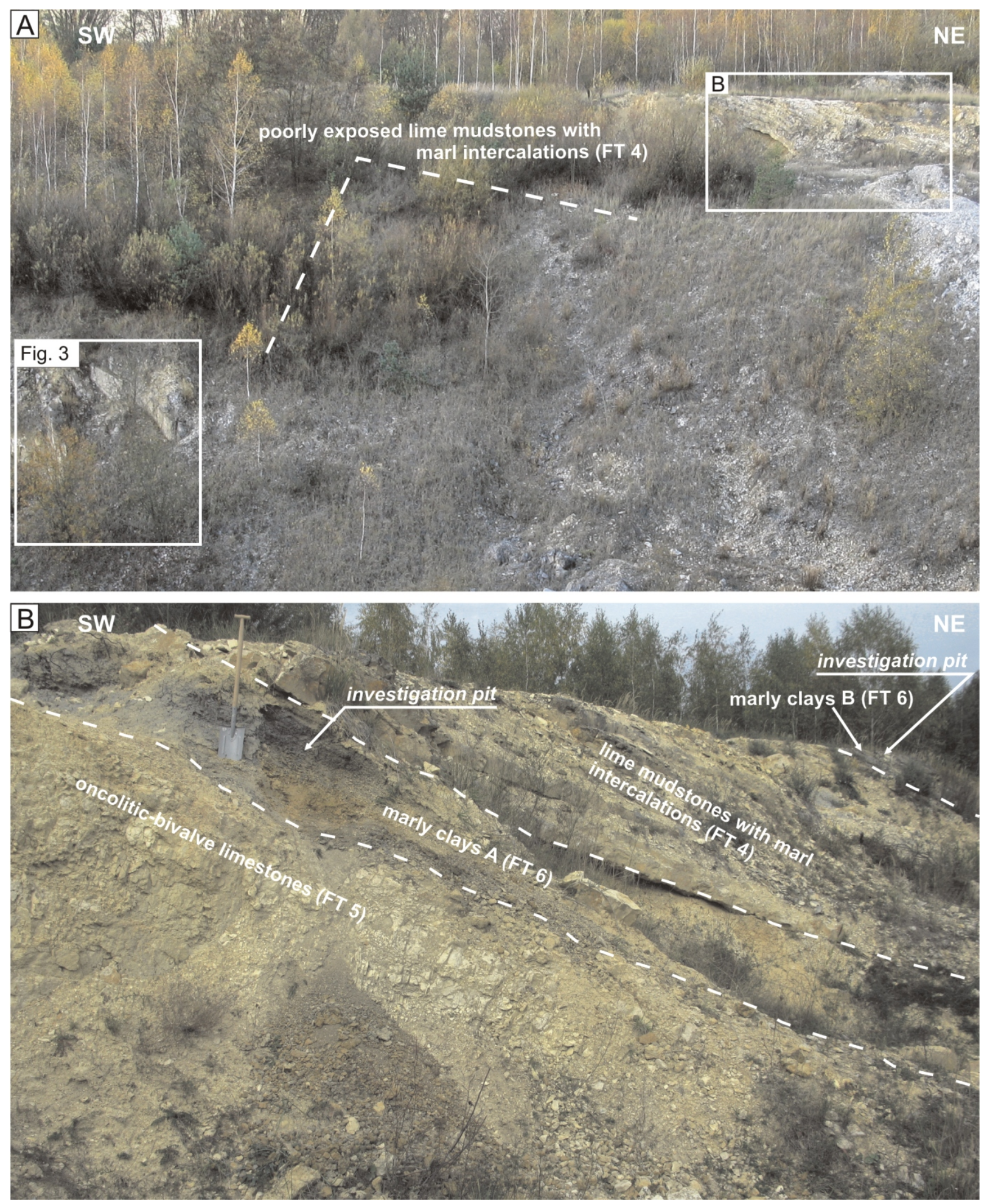

Fig. 2A - general view of exposures nos. 5 (Fig. 3) and 6 (frame B), with poorly exposed and gravel-covered lime mudstones with marl intercalations (FT 4 facies); B - no. 6 exposure in the western wall of the northern part of Rogaszyn Quarry with investigation pits, showing the facies types FT 4 to FT 6 (see description in text), inclination of the strata is visible 


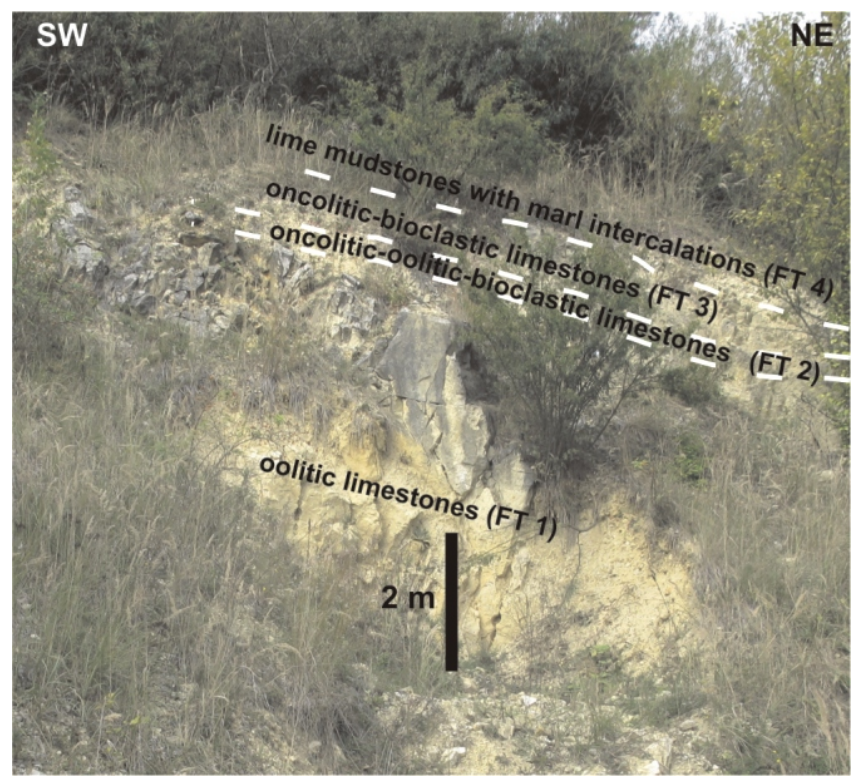

Fig. 3. General view of exposure no. 5, showing the oldest Upper Jurassic strata exposed in Rogaszyn Quarry, facies types FT 1 to FT 4 are differentiated

\section{MATERIALS AND METHODS}

Sedimentological characterization of the Lower Kimmeridgian succession from the Smotryszów Anticline was carried out in Rogaszyn Quarry, which is in two parts: a northern pit, recently partly in operation, and a southern pit, where limestone extraction ceased in the early 1990s (data for 2019; Fig. 1C). Rogaszyn Quarry does not show the full Upper Jurassic sequence in a single exposure. The strata dip at $\sim 22-30^{\circ}$ to the north-east and are exposed in various parts of vegetationand/or rubble-covered pits (Figs. $1 \mathrm{C}$ and 2-4). Moreover, a 2/82 oblique-slip fault with a throw reaching several metres was identified in exposure no. 4 (Figs. 1C and 4C). The operating pit, where the youngest Upper Jurassic strata are exposed, is covered by fresh limestone rubble, whereas the other parts of the quarry are mostly overgrown and/or covered by old limestone rubble. The Upper Jurassic strata were studied in several exposures (Fig. 1C), by a combination of detailed macroscopic observations in the field and microfacies analysis on 50 rock samples in the laboratory. Criteria used for classifications of ooids and oncoids were taken from Strasser (1986), Flügel (2004) and Védrine et al. (2007). Additionally, a few exploration pits were dug in order to better recognize the facies types and their distribution in the quarry. Detailed sedimentological profiles were constructed at the most important sampling sites (Figs. 2-5), including of facies and microfacies types, whereas only detailed macroscopic field observations were carried out at the remaining sites.

\section{FACIES AND MICROFACIES}

Six facies types (FT) are identified in the Upper Jurassic succession: oolitic limestones (FT 1), oncolitic-oolitic-bioclastic limestones (FT 2), oncolitic-bioclastic limestones (FT 3), lime mudstones and marls (FT 4), oncolitic-bivalve limestones (FT 5) and marly clays (FT 6). The characteristics of these facies are explained below, and illustrated in Figures 6-10.

\section{FT 1: OOLITIC LIMESTONES}

Field observations indicate that the sedimentary succession in Rogaszyn Quarry (observed in both the southern and the northern pits; Fig. 1C) starts with massive, thick-bedded oolitic limestones (Figs. 2A and 3). In the southern pit, the oolitic limestones are exposed at a few sites located on its lowermost bench (Fig. 1C). In the northern pit, the uppermost part of the oolitic limestones is exposed topographically slightly higher in relation to the lowermost portion of strata exposed in the opposite wall of the northern pit (exposure no. 4 in Fig. 1C). However, due to the northeastern dip of the strata, the oolitic limestones are older than the strata exposed in the eastern wall of the northern pit.

The observed thickness of the FT 1 facies in Rogaszyn Quarry reaches $5.5 \mathrm{~m}$ (Fig. 3). Two microfacies were distinguished: (1) oolitic-dominated grainstones (Fig. 7A-C) and (2) ooid-Bacinella-type oncoid grainstones-floatstones (Fig. 7D).

The ooid grainstones comprise densely packed ooids of rounded or slightly elliptical shape, up to $1.2 \mathrm{~mm}$ in size. At the contacts of many ooids, compactional deformations are observed. In some cases, the outermost parts of ooid cortices are cracked. Aggregate grains (up to $3 \mathrm{~mm}$ across) formed by ooids and bioclasts are also common, as well as irregular clasts, up to $3 \mathrm{~mm}$ across, composed of ooids cemented by grey calcisparite. Intergranular spaces are filled with blocky calcite cement (Fig. 7A-C). Based on the characteristics of the cortex, three ooid varieties are generally observed: (1) micritic, (2) radial-fibrous and (3) mixed, micritic/radial-fibrous (Fig. 7A-C), which correspond to ooids types 1, 3 and 4 after Strasser (1986) and Flügel (2004). The ooid nuclei are echinoderm fragments, foraminifers, gastropods or bryozoans. Well-sorted ooids with concentric lamination around the nuclei are most common (Fig. 7A-C), whereas those showing irregular laminae are scarce, and are similar to the eccentric ooids described by Gąsiewicz (1984). In many ooids, nuclei are difficult to recognize and their central parts are occupied by calcimicrite. Most common are radial-fibrous ooids (Fig. 7B), represented by well-rounded to slightly ellipsoidal shapes, laminated cortices and bioclastic nuclei. In some cases, lamination is obscured in the outer parts of cortices. Micritic type 1 ooids are smaller than the radial-fibrous variety (Fig. 7B). Under the microscope, they show dark-grey colouration and commonly recrystallized bioclastic nuclei rimmed by featureless cortices composed of dark micrite (Fig. 7A). Mixed, micritic/radial-fibrous ooids are common and larger in size than the micritic ooids. Their central parts contain dark micrite with or without recrystallized bioclasts as nuclei, while the outermost parts of cortices are composed of concentric radial-fibrous laminae (Fig. $7 \mathrm{C}$ ). In some cases, an initial stage of micritic laminae grades outwards into laminated radial-fibrous cortices followed by an outermost part composed again of micrite (Fig. 7C).

The second microfacies, which is observed in the upper part of the FT 1 sequence, includes mainly densely packed ooids and less common Bacinella-type oncoids (Fig. 7D). Ooids display more irregular shapes, and are poorly sorted in comparison with those described in the first microfacies (Fig. 7D). Some ooids are slightly elongated, others are rounded, ranging from 0.4 to $1.4 \mathrm{~mm}$ across. Most common are type 1 ooids with micritic or recrystallized bioclastic nuclei (Fig. 7D). In some ooids, the nuclei correspond to fragments of echinoderms, bivalves or bryozoans. However, in some specimens, the internal parts of the ooids are constituted by micritic fabric whereas the outer parts of their cortices are composed of several to more than ten faint, concentric laminae showing radial-fibrous structure. 

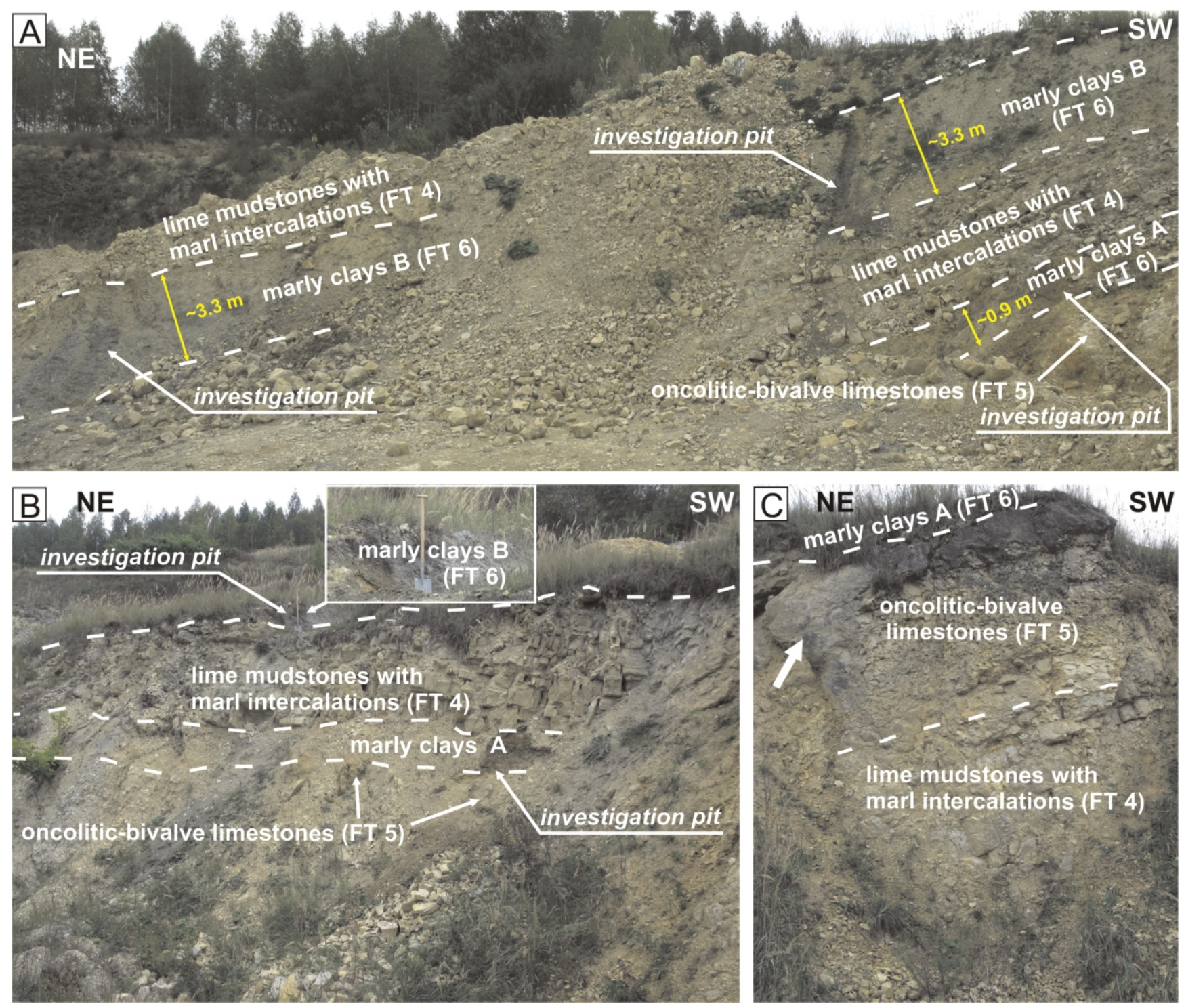

Fig. 4A - general view of exposure no. 1 with investigation pits within marly clays A and B; B - general view of the NE part of exposure no. 4 with investigation pits within marly clays $A$ and $B$ above oncolitic-bivalve limestones (FT 5) and lime mudstones with marl intercalations (FT 4); C - general view of exposure no. 4, the arrow indicates a fault surface

Ooids of this second microfacies may correspond to types 1, 3 and 4 after Strasser (1986) and Flügel (2004). Typical of this facies variety are Bacinella-type 3 oncoids (cf. Védrine et al., 2007), up to $2 \mathrm{~cm}$ in size, with a characteristic, irregular Bacinella-dominated meshwork (Fig. 7D) and oval to suboval shapes with smooth, wavy contours. Such oncoids commonly include smaller ooids and fragments of generally recrystallized echinoderms or bivalves in their internal parts. They are also intensively bored by Entobia isp., with characteristic chambers and canals representing the boring traces of carbonate-excavating sponges (e.g., Schlagintweit, 2010; Fig. 7D). Many chambers were colonized by the foraminifer Troglotella incrustans Wernli \& Fookes, which illustrates a common association of cryptoendolithic foraminifers and sponges. The second microfacies type also includes aggregate grains or clasts composed usually of several ooids cemented by dark calcimicrite, as well as cortoids represented by bioclasts with micritic envelopes. The intergranular spaces are filled with blocky cement with common admixture of dark microsparite. Relatively frequent are slightly elongated oncoids developed around fragments of commonly recrystallized bivalves, echinoderms and/or serpulids. The uppermost part of the FT 1 facies is separated from the overlying FT 2 facies by a hardground surface with numerous Lithophaga borings and bivalve encrustations (Fig. 6A).

Facies interpretation: The oolitic limestones facies FT 1 refers to the Standard Microfacies Type SMF 15 (e.g., Flügel, 2004) dominated by ooid grainstones with concentric and micritized ooids. Ooid depositional style represents Ramp Microfacies Type RMF 29 (Flügel, 2004), and took place on an inner ramp, in high-energy shoal and high- to moderate- energy back-shoal environments (see e.g., Kutek, 1968; Strasser, 1986; Tucker and Wright, 1990; Flügel, 2004). The ooid grainstones represent the high-energy shoal environment, which is documented by well-sorted grains, low diversity of fauna living on a mobile substrate or abraded biota. Similar Kimmeridgian facies were described by Bádenas and Aurell (2010) from oolitic-oncolitic-dominated ramp deposits in northeastern Spain, or from the high-energy shoal ramp settings in northern Germany (e.g., Kästner et al., 2008; Zuo et al., 2018). 


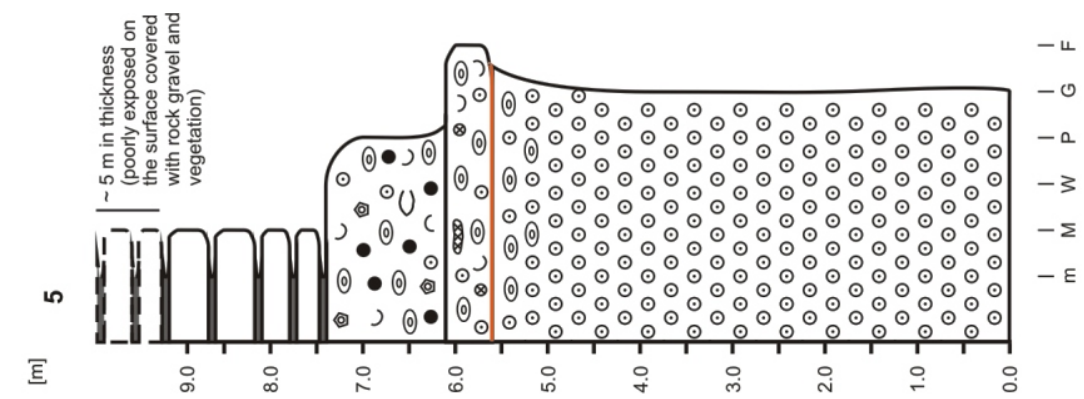

$\bullet$

\begin{tabular}{|l|l|l|l|}
\hline \multirow{5}{\leftarrow}{} & $\stackrel{m}{\leftarrow}$ & $\stackrel{N}{\leftarrow}$ & $\check{5}$ \\
\hline
\end{tabular}

E

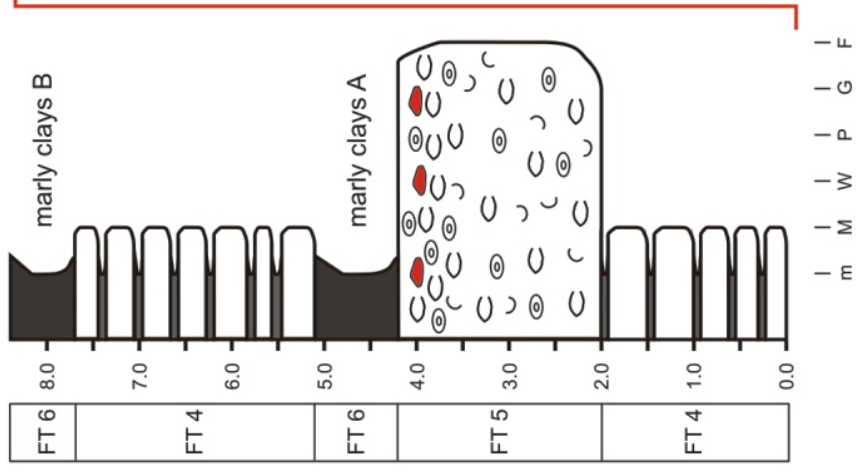

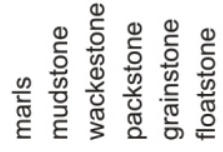

$E \Sigma 30 \mathrm{OL}$
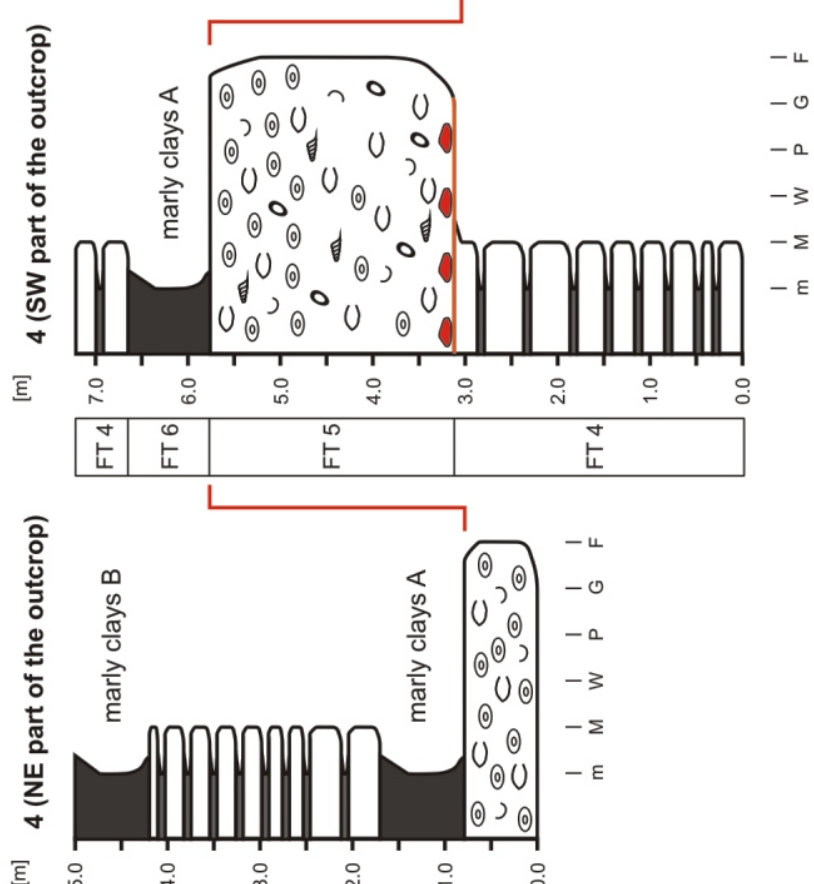

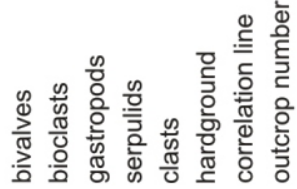

()

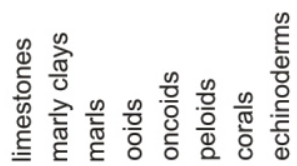
○ ○・

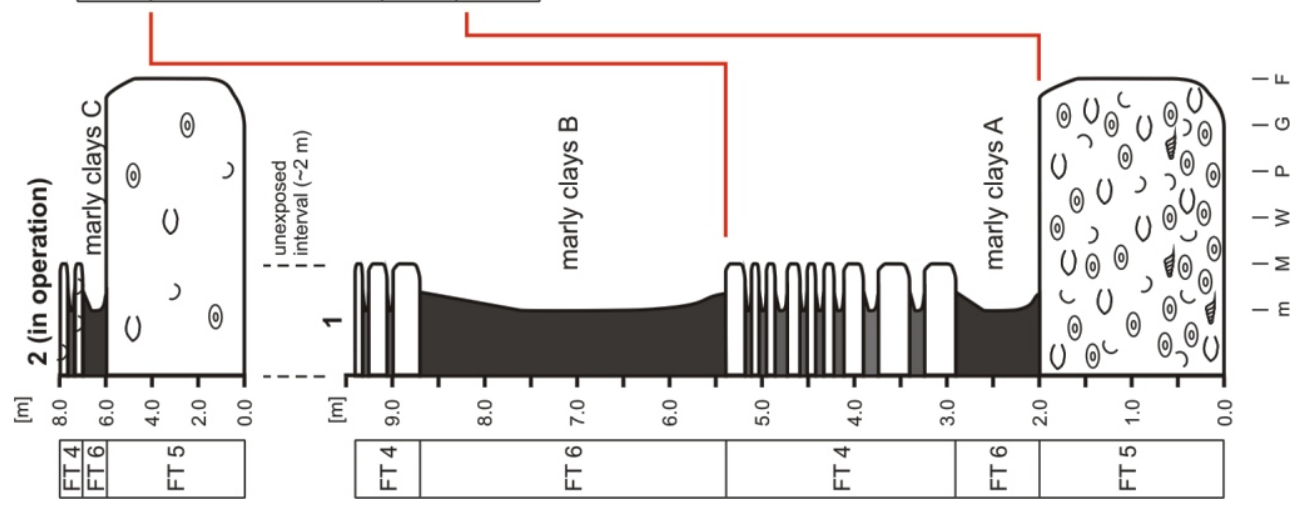



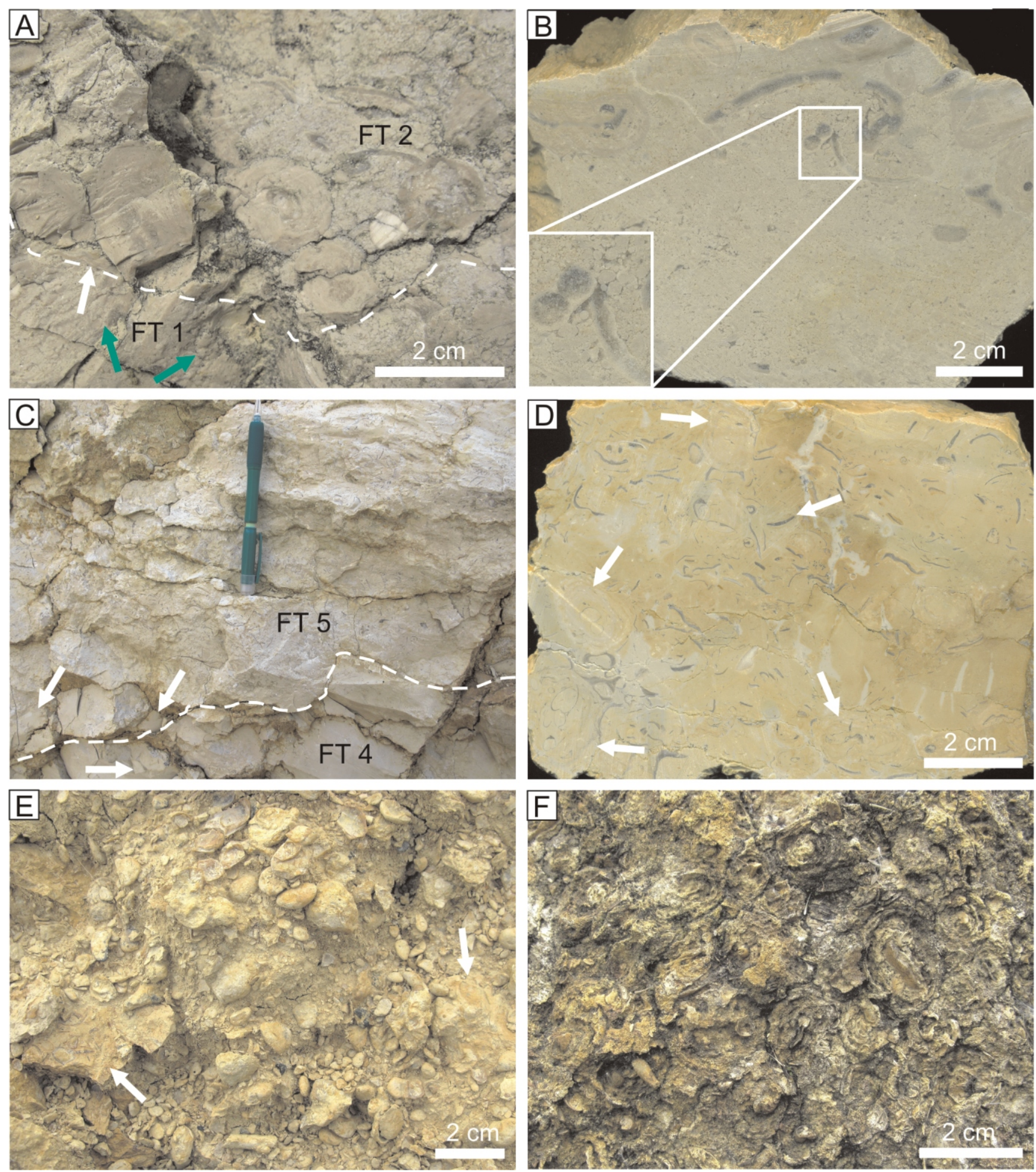

Fig. 6. Facies of the Upper Jurassic strata in selected exposures in Rogaszyn Quarry

A - irregular hardground separating oolitic limestones (FT 1) from oncolitic-oolitic-bioclastic limestones (FT 2; dashed line), bivalve (white arrow) and borings (green arrows) are observed close to the hardground, no. 5 exposure; B - oncolitic-oolitic-bioclastic limestones on polished slab (FT 2), the size of oncoids ranges from milimetres to some centimetres, no. 5 exposure; $\mathbf{C}$ - irregular erosional contact (dashed line) between lime mudstones with marl intercalations (FT 4) and oncolitic-bivalve limestones (FT 5), numerous angular limestone clasts are observed (arrows), no. 4 exposure; D - oncolitic-bivalve limestones on polished slab (FT 5) with numerous oval oncoids (arrows) and bivalves, no. 1 exposure; $\mathbf{E}$ - oncolitic-bivalve limestones (FT 5) with numerous Nanogyra and angular limestone clasts (arrows) embedded within marly matrix, no. 6 exposure; F - oncolitic-bivalve limestones (FT 5) with mass occurrence of oval oncoids up to some centimetres in size, no. 3 exposure 

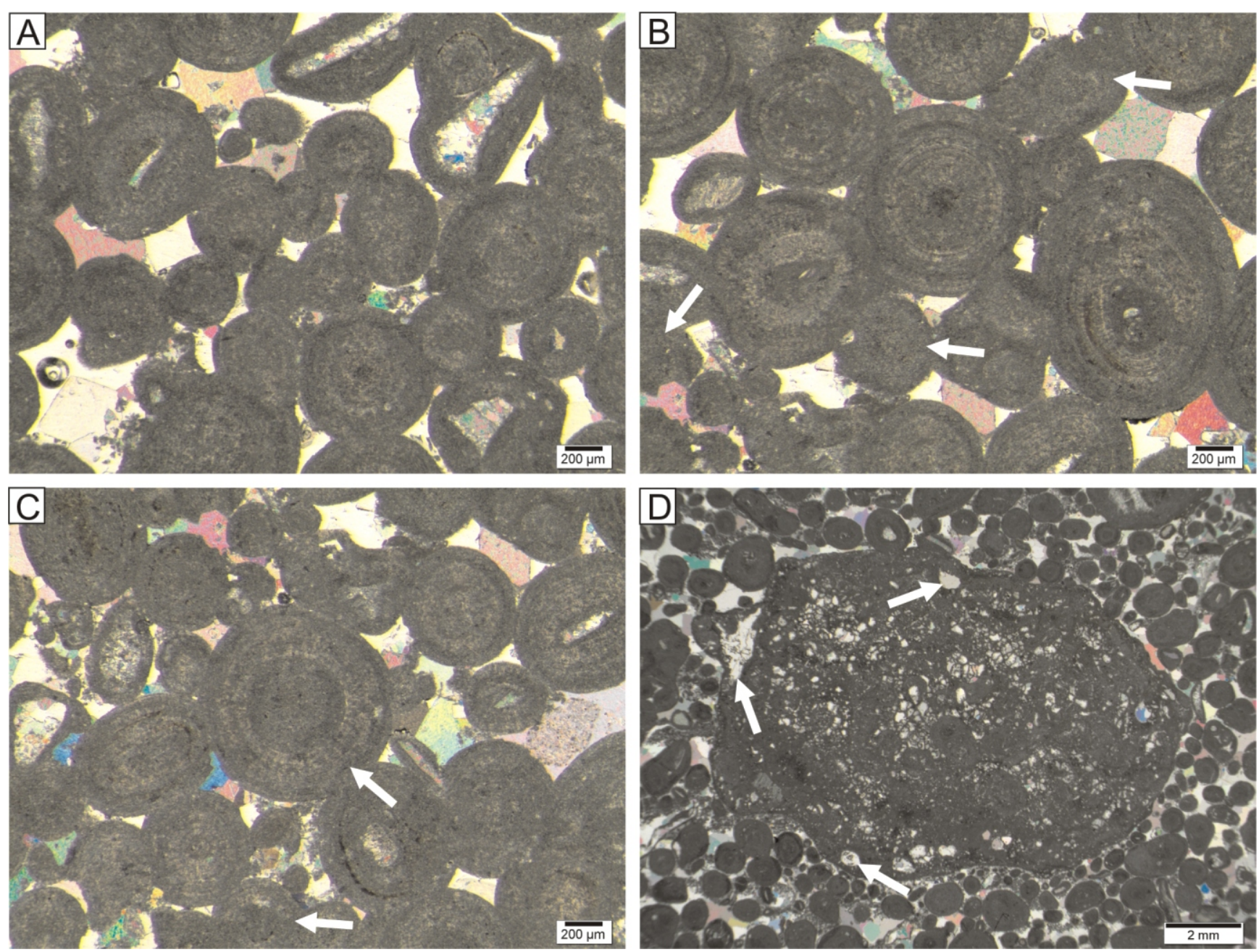

Fig. 7. Photomicrographs of the oolitic limestones (FT 1) in Rogaszyn Quarry

A - oolitic grainstone with well-sorted micritic ooids, spaces between ooids are filled with calcite blocky cement; B - oolitic grainstone with radial-fibrous ooids of well-rounded to slightly elipsoidal shapes and laminated cortices, individual micritic ooids are visible (arrows), smaller in size than the radial-fibrous ooids; $\mathbf{C}$ - micritic/radial-fibrous ooids (arrows) with micritic central parts and laminated outermost parts of cortices; D - ooid-Bacinella-type oncoid grainstones-floatstones with poorly sorted ooids, oncoid in central part of photograph is bored by Entobia isp. in its external part (arrows)

The upper part of the FT 1 facies represents back-shoal lagoon environments, showing typical features: poorly sorted grains and their micritization, which suggests stabilization of the sediment under moderate- and low-energy conditions. The presence of Bacinella-type oncoids may indicate low- to moderate-energy conditions with areas of increasing microbial activity (cf. Védrine et al., 2007; Bádenas and Aurell, 2010; Sequero et al., 2020). A sedimentation break is documented by the hardground developed on top of the FT 1 facies. A Lower Kimmeridgian inner-ramp ooid facies with Bacinella-type oncoids has also been described in central Poland, on the SW margin of the Holy Cross Mts. (Kutek and Radwański, 1965, 1967) and in the Szczerców area (Olchowy et al., 2019).

\section{FT 2: ONCOLITIC-OOLITIC-BIOCLASTIC LIMESTONES}

The FT 2 facies comprises mostly oncoid-ooid-bioclastic floatstones (Figs. 6A, B and 8A-D), up to $0.5 \mathrm{~m}$ in thickness
(Fig. 5). This facies is represented by poorly sorted coated grains, including oncoids, ooids, aggregate grains and cortoids, together with numerous fragments of corals though fewer than are oncoids and ooids. Three types of oncoid were identified: (1) micritic non-laminated, (2) micritic laminated and (3) fossil-bearing and micritic-laminated. The micritic, non-laminated oncoids correspond well to the type 1 oncoids distinguished by Védrine et al. (2007). They are oval or elliptical, some having slightly wavy contours, and reach diameters up to $1.9 \mathrm{~mm}$. The cortices are micritic, occasionally including recrystallized, oval foraminifers. The nuclei are recrystallized echinoderm or bivalve fragments, though in many oncoids the nuclei are composed of micrite. The micritic, laminated oncoids (type 1 after Védrine et al., 2007) present oval or rounded forms, up to $2.6 \mathrm{~mm}$ across, some with slightly wavy contours. Commonly recrystallized fragments of bivalve, echinoderm, gastropod or foraminifer constitute their nuclei, with occasional small, radial-fibrous ooids. The cortices are usually micritic and lami- 

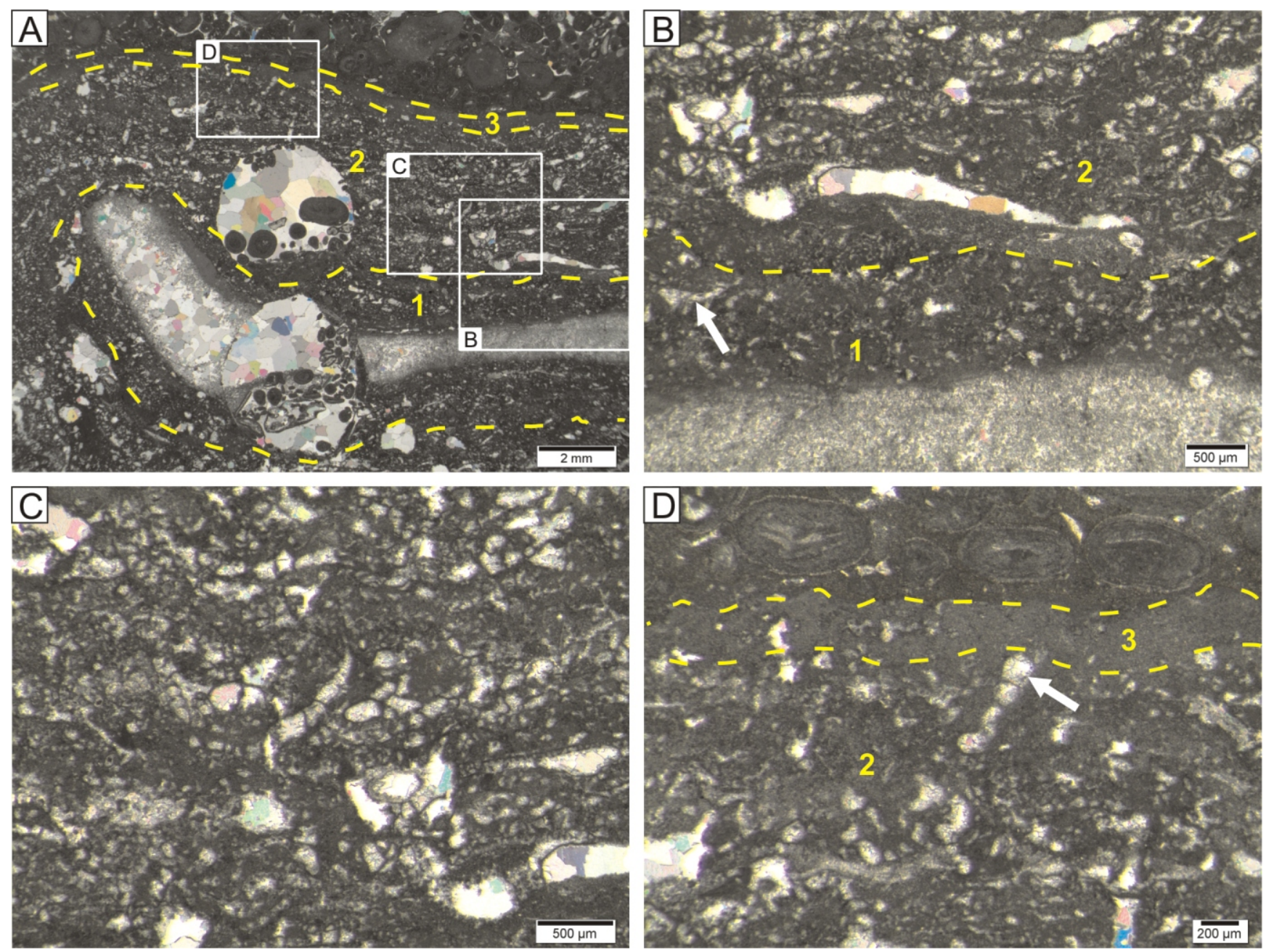

Fig. 8. Photomicrographs of the oncolitic-oolitic-bioclastic limestones (FT 2) from Rogaszyn Quarry

A - large oncoid with Litophaga borings and complex cortical internal structure, the central part of the oncoid is occupied by a recrystallized bivalve shell, which is surrounded by a micritic envelope no. 1, this envelope is separated from the fossil-bearing envelope no. 2 by a sharp boundary (dashed line), the outermost part of the oncoid corresponds to a micritic envelope no. 3; B - enlargement of sharp boundary (dashed line) separating micritic envelope no. 1 with sparry patches and individual elongated bioclast (arrow) outlining fine lamination in fossil-bearing envelope no. 2 in A; C - enlargement of fossil-bearing envelope no. 2 in A with irregular Bacinella meshwork, foraminifers and sparry patches; D - enlargement of external part of the fossil-bearing laminae no. 2 in A with recrystallized foraminifers and fragments of bivalves, separated from micritic laminae no. 3 (bounded by dashed lines) by sharp boundary, in the external part of the fossil-bearing laminae no. 2 Troglotella is observed (arrow), micritic envelope no. 3 with wavy edge contains individual foraminifers

nated, though in some cases can be difficult to distinguish. The micritic laminae are generally concentric, incorporating foraminifers, and some of them, especially the oval ones, can be truncated. The oncoids with fossil-bearing and micritic laminations are oval, with slightly undulose contours (Fig. 8A). They are larger and attain up to $1.6 \mathrm{~cm}$ across, and so can be included into the meso-oncoid or macro-oncoid categories (see Kutek and Radwański, 1965; Peryt, 1983; Flügel, 2004). Lithophaga borings are common, up to $5 \mathrm{~mm}$ in size, filled with blocky calcite cement, and including oncoids and ooids (Fig. 8A). The oncoid nuclei are commonly recrystallized fragments of bivalve or echinoderm (Fig. 8A). In smaller oncoids, the nuclei may correspond to small, micritic oncoids. The cortices of larger oncoids show a complex, zonal structure (cf. Sequero et al., 2020) with sharp boundaries between individual zones (Fig. 8A). A first growth stage of these cortices, up to $3 \mathrm{~mm}$ thick, is composed of micrite with recrystallized foraminifers, individual, fine bioclasts and borings, up to $1 \mathrm{~mm}$ in diameter, filled with dark micrite (Fig. 8A, B). In these parts of the oncoids, lamination is fine, commonly accentuated by thin, elongated bivalve shells (Fig. 8A). Occasionally, lamination is difficult to distinguish and the envelopes are constituted by dark micrite, in some cases encrusted by bivalves in their outermost parts. Such envelopes are covered by laminated, fossil-bearing cortices, up to $4 \mathrm{~mm}$ thick, with numerous, recrystallized fragments of bivalve, bryozoan and foraminifer, sparry patches and occasionally with irregular Bacinella-dominated meshworks with Troglotella (Fig. 8). The lamination is accentuated by elongated bivalve shells incorporated into the cortex (Fig. 8B). The outermost parts of oncoids show micritic envelopes with individual foraminifers and wavy outer parts (Fig. 8D). These oncoids correspond well to the type 2 oncoids distinguished by Védrine et al. (2007).

The ooids observed in the FT 2 facies are oval or slightly elongated, and reach up to $0.5 \mathrm{~mm}$ in diameter. Two of the three varieties described above were identified: (1) radial-fibrous and (2) mixed, micritic/radial-fibrous, which correspond to types 1, 3 and 4 ooids after Strasser (1986) and Flügel (2004). 

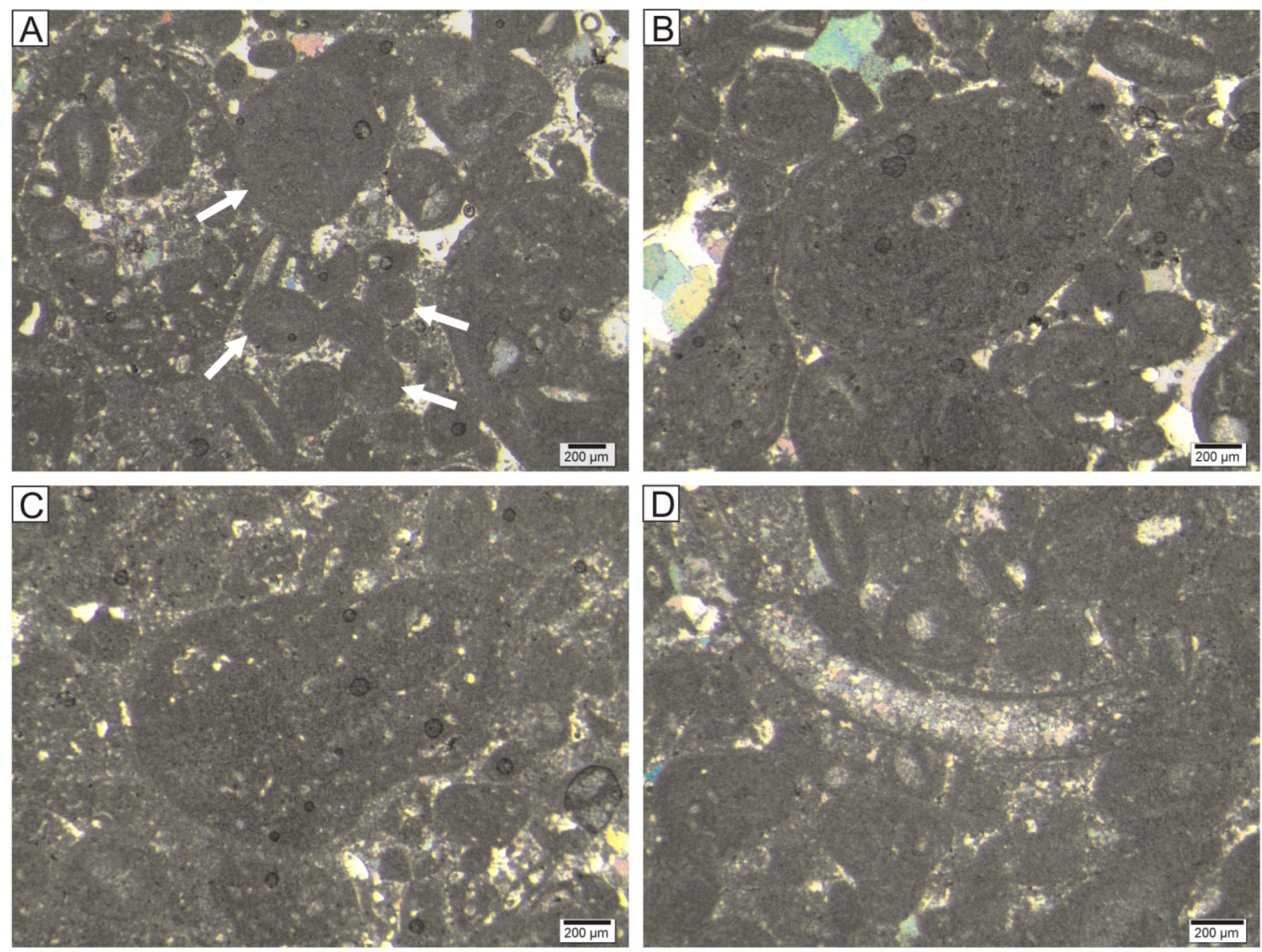

Fig. 9. Photomicrographs of the oncolitic-bioclastic limestones (FT 3) from Rogaszyn Quarry

A - poorly sorted micritic, non-laminated oncoids (arrows) with micritic nuclei; B - micritic-laminated oncoid (central part of photograph) with recrystallized foraminifer as nucleus, the cortex of the oncoid has concentric lamination with sparry patches, oncoid is surrounded by smaller micritic, non-laminated oncoids; C - fossil-bearing oncoid with wavy outline and laminated cortex with sparry patches and small recrystallized biodetritus; $\mathbf{D}$ - oncolitic-bioclastic packstone with micritic, non-laminated oncoids and cortoid in the central part of the photograph, the outermost part of the cortoid is a non-laminated, microbial-micritic envelope

The nuclei of radial-fibrous ooids are echinoderm or bivalve fragments, foraminifers or rare gastropods, and the laminae are concentric, only occasionally truncated. In the mixed, micritic-radial-fibrous ooids, the nuclei are foraminifers or micrite. The micritic fabric may occupy most parts of such ooids. In these cases, the outer parts are constituted by only a few laminae. Commonly, the micritic internal parts of ooids include recrystallized foraminifers.

Aggregate grains are frequent components of the FT 2 facies. They are rounded or wavy and may reach up to $1.7 \mathrm{~mm}$ across. The grains contain relatively small oncoids and ooids cemented with dark micrite. Some aggregate grains are enveloped by thin microbial laminae.

Cortoids are also common in the FT 2 deposits. They mostly correspond to elongated bioclasts, up to $3.5 \mathrm{~mm}$ in size, with non-laminated micritic rims, up to $0.2 \mathrm{~mm}$ thick. The thicknesses of the micritic rims can be consistent if their shapes are regular or may vary if their exteriors are wavy.

The transition of the FT 2 to the overlying FT 3 facies is gradual within a decimetre-thick zone and is revealed by a decreasing number and size of oncoids combined with an increasing number of peloids.
Facies interpretation: The oncolitic-oolitic-bioclastic limestones of the FT 2 facies correspond to the Standard Microfacies Types SMF 13 and 22 of Flügel (2004) dominated by oncoid-ooid-bioclastic floatstones/rudstones. Deposition of the FT 2 facies occured in an inner-ramp lagoonal environment, and represents the Ramp Microfacies Type RMF 21 (Flügel, 2004). This sedimentary environment was generally characterized by moderate water energy and low sedimentation rate, which is shown by the dominance of type 1 oncoids sensu Védrine et al. (2007). Some high-energy episodes are highlighted by the presence of ooids resedimented from both the shoal and the back-shoal parts of the ramp, as well as by the presence of coral fragments derived from adjacent areas. Such episodic high-energy conditions are also shown by locally truncated micritic laminae observed in some of the oncoids studied. The type 2 oncoids with complex cortices represent different stages of oncoid growth under variable water energy and microbial activity conditions. The presence of the characteristic Bacinella-dominated meshwork and micritic envelopes in the external parts of type 2 oncoids suggests increasing microbial activity under low-energy conditions. 


\section{FT 3: ONCOLITIC-BIOCLASTIC LIMESTONES}

The FT 3 facies comprises oncolitic-bioclastic packstones and less common wackestones, up to $\sim 1.5 \mathrm{~m}$ thick (Fig. 3). The coated grains are represented by oncoids, cortoids and individual ooids, up to $0.5 \mathrm{~mm}$ in size. Three varieties of oncoid were identified: (1) micritic, non-laminated, (2) micritic, laminated and (3) fossil-bearing (Fig. 9). The micritic, non-laminated oncoids predominate (Fig. 9A), up to $1.6 \mathrm{~mm}$ across (usually $\sim 0.5 \mathrm{~mm}$ ), showing ellipsoidal or spheroidal forms. They correspond well to type 1 oncoids distinguished by Védrine et al. (2007). Their nuclei are foraminifers, bivalve shells or fragments of echinoderm, commonly recrystallized, but many oncoids show micritic nuclei (Fig. 9A). The micritic, laminated oncoids are spherical or oval in shape (Fig. 9B), showing similar diameters to the non-laminated variety. The nuclei are recrystallized fragments of bivalve, echinoderm or foraminifer, but in some oncoids correspond to microsparite, lighter in colour than the microsprite observed in the cortex, and showing diffuse boundaries. The cortices are composed of poorly recognizable, concentric laminae, locally incorporating sparry patches (Fig. 9B). The micritic, laminated variety resembles type 1 oncoids sensu Védrine et al. (2007). The fossil-bearing oncoids, which correspond to type 2 oncoids after Védrine et al. (2007), are relatively rare. They are spheroidal with slightly wavy exteriors and show diameters up to $1.9 \mathrm{~cm}$, being the largest among all the oncoids described (Fig. 9C). The nuclei comprise recrystallized fragments of bivalve, echinoderm or scarce gastropod, whereas the cortices are distinctly laminated with microbial-micritic laminae, in which sparry patches and recrystallized bivalve or echinoderm fragments can be found (Fig. 9C).

Cortoids are common in the FT 3 facies. Their shapes follow the enclosed bivalves, echinoderms, bryozoans or gastropods, surrounded by thin (up to $0.3 \mathrm{~mm}$ ), dark, non-laminated, microbial-micritic envelopes with scarce sparry patches (Fig. 9D). Other components of the FT 3 facies are radial-fibrous ooids with concentric lamination and aggregate grains composed of oncoids and peloids. Oval or slightly elongated peloids are frequent, up to $0.2 \mathrm{~mm}$ in size, composed of dark, structureless micrite with usually clearly visible exteriors. Up-sequence, the FT 3 facies grades into lime mudstones intercalated with marly limestones representing the FT 4 facies.

Facies interpretation: The FT 3 facies corresponds to standard microfacies types SMF 10 or SMF 11 after Flügel (2004). The FT 3 facies was deposited in an inner ramp setting, under relatively low- to moderate energy conditions of a semi-restricted or fully marine lagoon. The prevalence of micritic oncoids may suggest a lagoonal environment of moderate energy. Such oncoids are typical of peloidal-bioclastic lagoons (Védrine et al., 2007). Episodic relatively high-energy conditions are suggested by the presence of type 2 oncoids and ooids originated from the ramp shoals. Similar facies are described from shallow-water Kimmeridgian carbonate ramps in northeastern Spain (Bádenas and Aurell, 2010) and in Northern Germany (e.g., Zuo et al., 2018).

\section{FT 4: LIME MUDSTONES WITH MARL INTERCALATIONS}

The FT 4 facies, up to several metres thick (Fig. 2), is mainly represented by lime mudstones, up to $25 \mathrm{~cm}$ thick, intercalated with marls (up to $5 \mathrm{~cm}$ thick; Fig. 5). The boundaries of these two lithologies are sharp, with common Thalassinoides burrows. A typical feature is a fine fissility of the sediments. In the field, the lime mudstones appear as homogeneous beds. Under the microscope, a dark, micritic fabric with individual small burrows is observed, enclosing packets up to $2.5 \mathrm{~mm}$ thick composed of several thin, light-coloured laminae intercalated with thicker laminae of darker micrite (Fig. 10A). The laminae are inclined at the angles up to a dozen degrees. The light-coloured laminae are coarser-grained compared to the darker ones, and show wackestone-packstone textures with numerous but dispersed fragments of echinoderm, gastropod, foraminifer and thin-shelled bivalve. The boundaries of such laminae are distinct, straight or slightly wavy. Some laminae can be disturbed by burrows with diffuse boundaries. In such cases, the individual laminae bend or terminate at the contacts with the burrows (Fig. 10A). Locally, in the micritic fabric, wavy, discontinuous laminae are observed, up to $\sim 1 \mathrm{~cm}$ long, showing wackestone textures with very fine, dispersed bioclasts and quartz grains. The marls contain scarce small bioclasts and burrows. The FT 4/FT 5 boundary is sharp but undulose and accentuated by fragments of bivalves and angular limestone clasts (Fig. 6C).

Facies interpretation: The origin of the marl/limestone alternations in the FT 4 facies remains unclear. Similar successions have already been discussed by, e.g., Westphal et al. (2008) and Colombié et al. (2012). These deposits may result from environmental cyclicity (e.g., sea level or climate changes), diagenetic overprint or a combined effect of both (see e.g., Einsele and Ricken, 1991; Munnecke and Samtleben, 1996; Westphal et al., 2010; Colombié et al., 2012). Marl/limestone alternations are known to form in both pelagic and shallow-marine environments (Einsele and Ricken, 1991; Munnecke et al., 1997). In the case under study, the FT 4 lime mudstones with marl intercalations alternate with inner-ramp shoal, back-shoal and lagoonal deposits. In particular, this facies appears in the succession between the lagoonal deposits of the FT 3 and FT 5 facies, as well as between marls A and B of the FT 6 facies (see below; Fig. 5). These facies relationships suggest that the FT 4 deposits formed in an inner ramp environment (SMF 23 and/or RMF 19 varieties after Flügel, 2004), with scarce shallow-water biota of low diversity, dominated by thin-shelled bivalves, gastropods and echinoderms (see also Alexandrowicz and Barwicz-Piskorz, 1974; Barwicz-Piskorz, 1992, 1995; Matyja, 2011). The low-angle cross-lamination was probably caused by storm waves (Myrow et al., 2002) or currents intermittently supplying the clastic sediment, including quartz grains. The marl intercalations commonly contain burrows in their upper parts, filled by lime mudstone. These features may indicate the effect of cyclic environmental changes within the inner-ramp environment, rather than the effect of diagenetic processes (e.g., Clombié et al., 2012). The burrowed sharp boundaries between marls and lime mudstone layers may suggest reworking or low sedimentation rates (Flügel, 2004), which may reflect changes in relative sea level and/or climate conditions. Detailed investigations of similar facies may reveal that the Upper Jurassic shallow-water, marl-limestone alternations correspond to sedimentary sequences related to low-amplitude, high-frequency sea-level changes in tune with orbital precession cycles (see e.g., Colombié et al., 2012; Strasser et al., 2012).

\section{FT 5: ONCOLITIC-BIVALVE LIMESTONES}

This facies type, up to $3 \mathrm{~m}$ thick (Fig. 2), is bipartite. The boundary between the FT 5 and the underlying FT 4 facies is a 

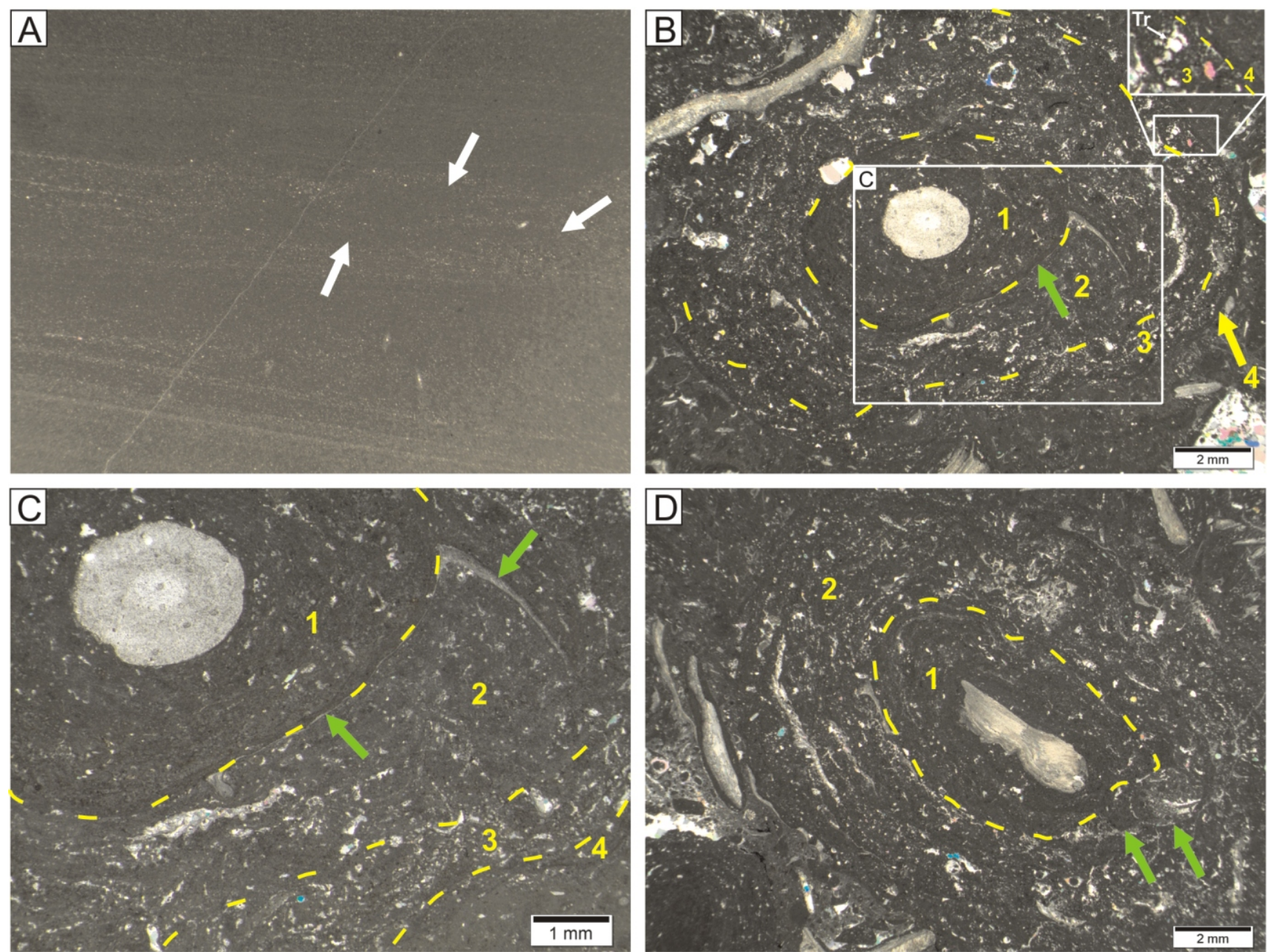

Fig. 10. Photomicrographs of the lime mudstones with marl intercalations (FT 4) and oncolitic-bivalve limestones (FT 5) from Rogaszyn Quarry

A - lime mudstone with inclined light-coloured laminae intercalated with darker micrite laminae, some laminae are disturbed by burrows (arrows), lime mudstones with marl intercalations (FT 4); B, C - oval oncoid with complex internal structure, the boundaries between envelopes nos. 1-4 are sharp (dashed lines), the internal part of the oncoid is occupied by an echinoderm fragment, which is surrounded by dark no. 1 micritic envelope, no. 2 fossil-bearing envelope contains numerous bioclasts and sparry patches, the contact between envelopes nos. 1 and 2 is locally outlined by a thin bivalve shell (green arrows), no. 3 envelope has an irregular Bacinella-dominated fabric with individual Entobia isp. chambers and Troglotella (Tr), the outermost no. 4 envelope is a microbial structureless encrustation (yellow arrow), oncolitic-bivalve limestones (FT 5); D - laminated oncoid with bioclastic nucleus and two types of envelope: no. 1 micritic laminated and no. 2 fossil-bearing with borings (arrows), oncolitic-bivalve limestones (FT 5)

sharp but irregular contact surface (Fig. 6C). The lower part of the FT 5 facies, $\sim 1.5 \mathrm{~m}$ thick, is represented by bioclastic floatstones with abundant but chaotically distributed fragments of bivalve, brachiopod (up to $1.5 \mathrm{~cm}$ in size), serpulid and gastropod. In the FT 4/FT 5 contact zone, $\sim 30 \mathrm{~cm}$ thick, angular limestone clasts of FT 4 are also abundant (Fig. 6C), gradually disappearing up-sequence. The upper part of the FT 5 succession, $1.5 \mathrm{~m}$ thick, comprises oncoid floatstones-rudstones with a diverse assemblage of bivalves (including Nanogyra) and brachiopods, generally within a marly matrix with common limestone clasts of FT 5 (up to $6 \mathrm{~cm}$ in size) and oval oncoids (Fig. 6E). The oval oncoids, up to $\sim 3 \mathrm{~cm}$ in diameter (but usually from 1 to $2 \mathrm{~cm}$ ), with slightly wavy exteriors (Fig. 6D), are the dominant coated grains in the FT 5 facies. Regarding their size, they are comparable with macro-oncoids sensu Kutek and Radwański (1965) and Peryt (1983). The oval oncoids have a complicated internal structure (Figs. 10B-D and 11A-C). Their nuclei are bivalve (including Nanogyra), brachiopod or echinoderm frag- ments, surrounded by dark, micritic envelopes (up to $3 \mathrm{~mm}$ thick) followed then by distinct, fossil-bearing, concentric laminations, which incorporate bioclasts, sparry patches (Figs. 10B, $C$ and $11 \mathrm{~A}-\mathrm{C}$ ) and occasional borings (Fig. 10D). The outer edges of such envelopes are sharp and wavy, commonly bored and encrusted by bivalves (Figs. 10B, C and 11C). These envelopes grade into fossil-bearing envelopes (up to $4 \mathrm{~mm}$ thick) including more bioclasts (elongated bryozoans, bivalves or serpulids), which form encrustations accentuating the cortical lamination (Figs. 10B, C and 11A-C). Sparry patches, foraminifers and Lithophaga borings are also frequent. The outermost edges of these envelopes can be sharp or diffuse, the latter occurring in the absence of thin, elongated bivalve shells or bryozoans, and where Bacinella-dominated fabric of the next envelope causes diffusion of the boundaries. These Bacinella-dominated overlying envelopes, up to $\sim 2 \mathrm{~mm}$ thick, contain individual chambers of Entobia isp., as well as foraminifers (including Troglotella incrustans, Figs. 10B and 

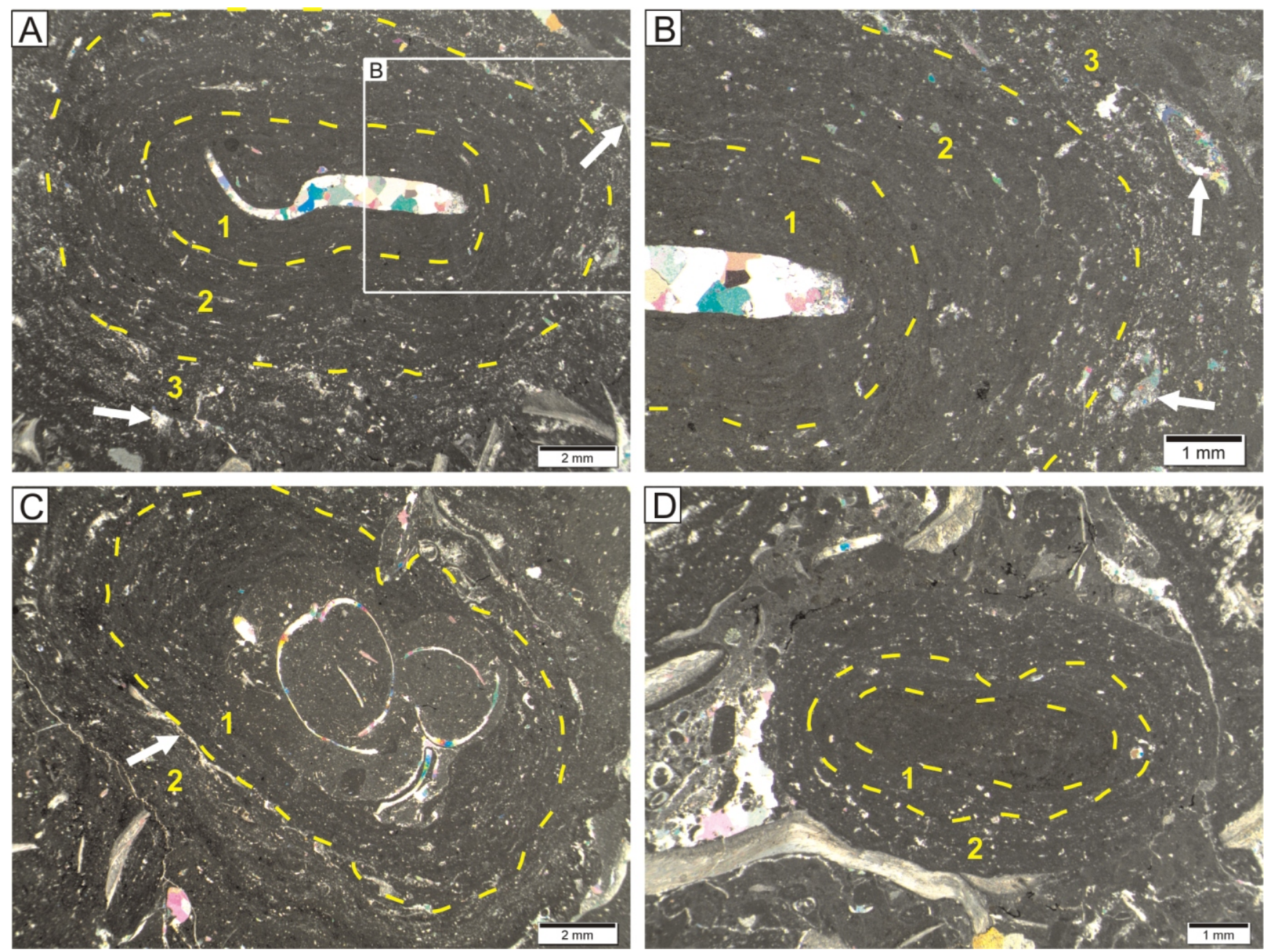

Fig. 11. Photomicrographs of the oncolitic-bivalve limestones (FT 5) from Rogaszyn Quarry

A, B - oval oncoid with complex internal structure of laminated cortex, the central part of the oncoid is occupied by a recrystallized bivalve shell covered by a finely laminated no. 1 micritic envelope, no. 2 envelope contains numerous small bioclasts, commonly elongated, which emphasize its lamination, no. 3 envelope has an irregular Bacinella-dominated fabric with individual Entobia isp. chambers (arrows); C - oval oncoid with borings filled with micrite and fine bioclasts, the borings (internal part of the oncoid) are covered by a micritic cortex of varying thickness including dispersed bioclasts (no. 1 envelope), the outermost part of the oncoid is a fossil-bearing envelope no. 2 separated locally from the previous envelope by bivalve shells (arrow); D - oncoid with micritic, structureless dark coloured nucleus sharply separated (dashed line) from a micritic envelope no. 1 with dispersed sparry patches, the external envelope no. 2 is made of finely laminated micrite with disperse bioclasts and sparry patches

$11 \mathrm{~A}, \mathrm{~B})$. Finally, these envelopes have microbial coatings, up to $\sim 300 \mu \mathrm{m}$ thick (Fig. 10B, C), with locally visible lamination. The oval oncoids correspond to type 3 oncoids after Védrine et al. (2007; cf. Sequero et al., 2020).

Oncoids up to $\sim 1 \mathrm{~cm}$ in size are usually slightly elongated, show regular internal contours and have bioclastic or micritic nuclei (Fig. 11D). The micritic nuclei, up to $1.5 \mathrm{~mm}$ thick, are dark and structureless, with occasional small sparry patches. The cortices, usually $\sim 3 \mathrm{~mm}$ in diameter, are concentrically laminated, with thin, elongated bryozoans and bivalves encrusting the individual laminae. Some laminae may incorporate small bioclasts, foraminifers (Bullopora) and serpulids. Such oncoids are similar to type 2 oncoids sensu Védrine et al. (2007) and, considering their size, they correspond to the meso-oncoids of Kutek and Radwański (1965), Peryt (1983) and Flügel (2004).

The FT 5 facies also contains cortoids, up to $\sim 6 \mathrm{~mm}$ in size, which correspond to elongated bivalve, brachiopod or echinoderm bioclasts enveloped by structureless microbial coatings, up to $300 \mu \mathrm{m}$ thick.
Facies interpretation: The FT 5 facies represents the SMF 12 in the lower part, and the SMF 13 in the upper part (both sensu Flügel, 2004). Sedimentation during most of deposition of the FT 5 facies occurred in a fully marine lagoon with low sedimentation rate, as revealed by the presence of type 3 oncoids (Védrine et al., 2007; Sequero et al., 2020). Gastropods and mass occurences of bivalve coquinas may be related to high, although episodic, supply of nutrients to a restricted lagoon (see e.g., Dupraz and Strasser, 1999; Flügel, 2004; Kästner et al., 2008; Zuo et al., 2018). Moreover, the presence of suspension-feeding bivalves suggests that large amounts of food particles were suspended in the water column (e.g., Flügel, 2004: 624). Lower Kimmeridgian oncoid-bivalve limestones are widely distributed in central Poland (see e.g., Kutek and Radwański, 1965, 1967; Kutek, 1968; Barwicz-Piskorz, 1995; Olchowy et al., 2019). Similar mass accumulations of diverse assemblages of oyster shells forming layers up to $10 \mathrm{~m}$ thick are typical of the Kimmeridgian strata of the SW margin of the Holy Cross Mts. (Machalski, 1998; Zatoń and Machalski, 2013). Such accumulations formed mostly under high-energy condi- 
tions. Accumulations of Nanogyra shells (up to $10 \mathrm{~cm}$ thick) are known also from Kimmeridgian strata in northern and western France, and are interpreted as storm deposits (Fürsich and Oschmann, 1986). It seems that the Nanogyra occurrences of Rogaszyn Quarry also reflect deposition in a high-energy environment, as indicated by the chaotic orientation and fragmentation of the shells, and the presence of limestone clasts of FT 5 These clasts may indicate syndepositional cementation of sediment, probably leading to hardground formation and a hiatus before reworking.

\section{FT 6: MARLY CLAYS}

In Rogaszyn Quarry, the marly clays comprise three units which occur after deposition of the FT 4 and FT 5 facies: (1) unit $A-0.9$ m thick, (2) unit B $-3.3 \mathrm{~m}$ thick and (3) unit $\mathrm{C}-\sim 1.0 \mathrm{~m}$ thick, all of these characterized by dark grey, homogeneous deposits devoid of fossils and burrows. Only at the contact with the underlying FT 5 deposits, the colour of the marly clays changes into yellowish, greyish or brownish within an interval of some tens of centimetres. The marly clay units A and B show consistent thicknesses and lithologies across the whole quarry (Figs. 2B, 4A, B and 5). Depending on the dip and strike of the beds, and the orientation of the quarry walls, the marly clay units can be examined at various sites of the quarry. The field observations of lithology and thickness of these strata together with lithologic profiles (Figs. 2, 4 and 5) enable the authors to conclude that both the marly clay units $A$ and $B$ provide good correlation horizons in the Rogaszyn Quarry (Fig. 5). The contacts of these marly clays with both the FT 4 and FT 5 facies are sharp and depositional.

Facies interpretation: the interpretation of the depositional environment of these marly clays is ambiguous. On the basis of the vertical relationships of this facies with its under- and overlying facies types (Figs. 2, 4 and 5), the small thickness of this succession together with the recurrence of facies types and the presence of shallow-water, inner-ramp facies types accompanying FT 6 in the vertical profile suggest that the FT 6 facies may represent deposition resulting from episodes of more humid climate and intensified supply of terrigenous material.

\section{LITHOSTRATIGRAPHIC POSITION OF THE UPPER JURASSIC STRATA IN THE ROGASZYN QUARRY AREA}

The Upper Jurassic sedimentary succession of the Smotryszów Anticline was previously reconstructed using borehole data (Barwicz-Piskorz, 1992, 1995) and outcrops (e.g., Kutek, 1968; Wierzbowski and Głowniak, 2018), which has enabled us to better characterize and integrate this Lower Kimmeridgian sedimentary succession as well as to compare it with the neighbouring Upper Jurassic successions of the southern, peripheral part of the Łódź Depression (Szczerców area Fig. 12), analysed using borehole data by Olchowy et al. (2019).

The Upper Jurassic sedimentary succession of the Smotryszów Anticline (Kodrąb area) begins with "Chalky Limestone" with corals and cherts (Fig. 12B). Its incomplete, borehole-constrained thickness is $\sim 10 \mathrm{~m}$ (Barwicz-Piskorz, 1992, 1995). This limestone unit corresponds to the Lower Kimmeridgian (Planula Zone, dated by ammonites) coral and pelitic facies described by Kutek (1968), and can be compared with the upper part of the microbial-sponge limestones found by
Olchowy et al. (2019) in the adjacent Szczerców area (F 2 facies in Fig. 12A). In these limestones, corals and cherts are present together with sponges. In the Smotryszów Anticline, the overlying, $\sim 25 \mathrm{~m}$ thick, grey marly limestones and marls containing rare bioclasts may correspond to the fine-grained and pelitic limestones ( $F 5$ facies) and to the marly limestones and marls ( $\mathrm{F} 6$ facies) of the Szczerców area, with a total thickness of $\sim 17 \mathrm{~m}$, described by Olchowy et al. (2019). Up-sequence of the Kodrąb area, the "Chalky Limestone" member with abundant corals appears again with a thickness of $\sim 60 \mathrm{~m}$, and can be correlated with the "Coral Formation" sensu Dembowska (1979) encountered in the adjacent Szczerców area (Mrozek, 1975; Barwicz-Piskorz, 1992; Krajewski et al., 2014, 2019; Olchowy et al., 2019), represented by up to $35 \mathrm{~m}$ of coral and pelitic limestones ( $F 7$ facies), described by Olchowy et al. (2019). Moreover, the coral facies also extends to the east, along the SW and NW margins of the Holy Cross Mts. (see e.g., Kutek, 1968; Roniewicz and Roniewicz, 1971; Alexandrowicz and Barwicz-Piskorz, 1974; Matyja, 2011). In the upper part of the "Chalky Limestone" member of the Smotyszów Anticline, an $\sim 2 \mathrm{~m}$ thick interval is found with numerous oncoids (including macro-oncoids with Bacinella; Kutek, 1968; Kutek and Radwański, 1965). This characteristic oncolitic facies is encountered also in the Szczerców area ( $\mathrm{F} 8$ facies, up to $3 \mathrm{~m}$ thick, after Olchowy et al., 2019). According to Barwicz-Piskorz (1992, 1995), in the Kodrab area, the "Chalky Limestone" is overlain by pelitic limestones with intercalations of detrital limestone and marl, up to $\sim 30 \mathrm{~m}$ thick (Fig. 12B). Considering the lithology, these deposits are comparable to pelitic limestones laterally interfingering with coral and pelitic limestones in the Szczerców area ( $F 7$ facies, after Olchowy et al., 2019; Fig. 12A). However, in the Szczerców area, no marls were encountered in the $F 7$ pelitic facies, despite occurring as thin intercalations in the Kodrąb succession (Fig. 12B). Moreover, in Smotryszów Quarry, Kutek (1968) described an oncolitic facies, $\sim 9 \mathrm{~m}$ thick, showing a single intercalation of pelitic limestone in the upper part of the "Chalky Limestone" member. Furthermore, Kutek (1968: 527) observed that, in the Smotryszów Quarry, this facies is overlain by marls grading upwards into the pelitic limestones and suggested their continuation in the Rogaszyn Quarry (see also Wierzbowski and Głowniak, 2018). This proposal was later supported by observations made in borehole cores from the Kodrąb and the Szczerców areas (e.g., Barwicz-Piskorz, 1995).

In both the Smotryszów and the Rogaszyn areas, these sedimentary successions are overlain by inclined layers comprising the "Lowermost Marly Horizon", several tens of metres thick, (Platynota Zone after Kutek, 1994) and an oolitic facies (Barwicz-Piskorz, 1992, 1995), the latter representing the "Oolitic Formation" sensu Dembowska (1979). It is probable that the marly shales observed above the coral and the oncolitic facies in the Smotryszów Quarry (Kutek, 1968) represent part of the "Lowermost Marly Horizon" (see also Barwicz-Piskorz, 1995), whereas the oolitic facies cropping out nowadays in the Rogaszyn Quarry (FT 1 facies described in this work) may be included into the upper part of the "Oolitic Formation" after Dembowska (1979). This assumption seems to be logical considering the inclination of beds and the distance between the Smotryszów and Rogaszyn quarries, and it is also supported by borehole core data (Barwicz-Piskorz, 1992, 1995) and descriptions of strata in the adjacent Szczerców area (Olchowy et al., 2019) and at the SW margin of the Holy Cross Mts. (Kutek, 1968; Alexandrowicz and Barwicz-Piskorz, 1974; BarwiczPiskorz, 1992, 1995; Matyja, 2011). The oolitic facies in Roga- 


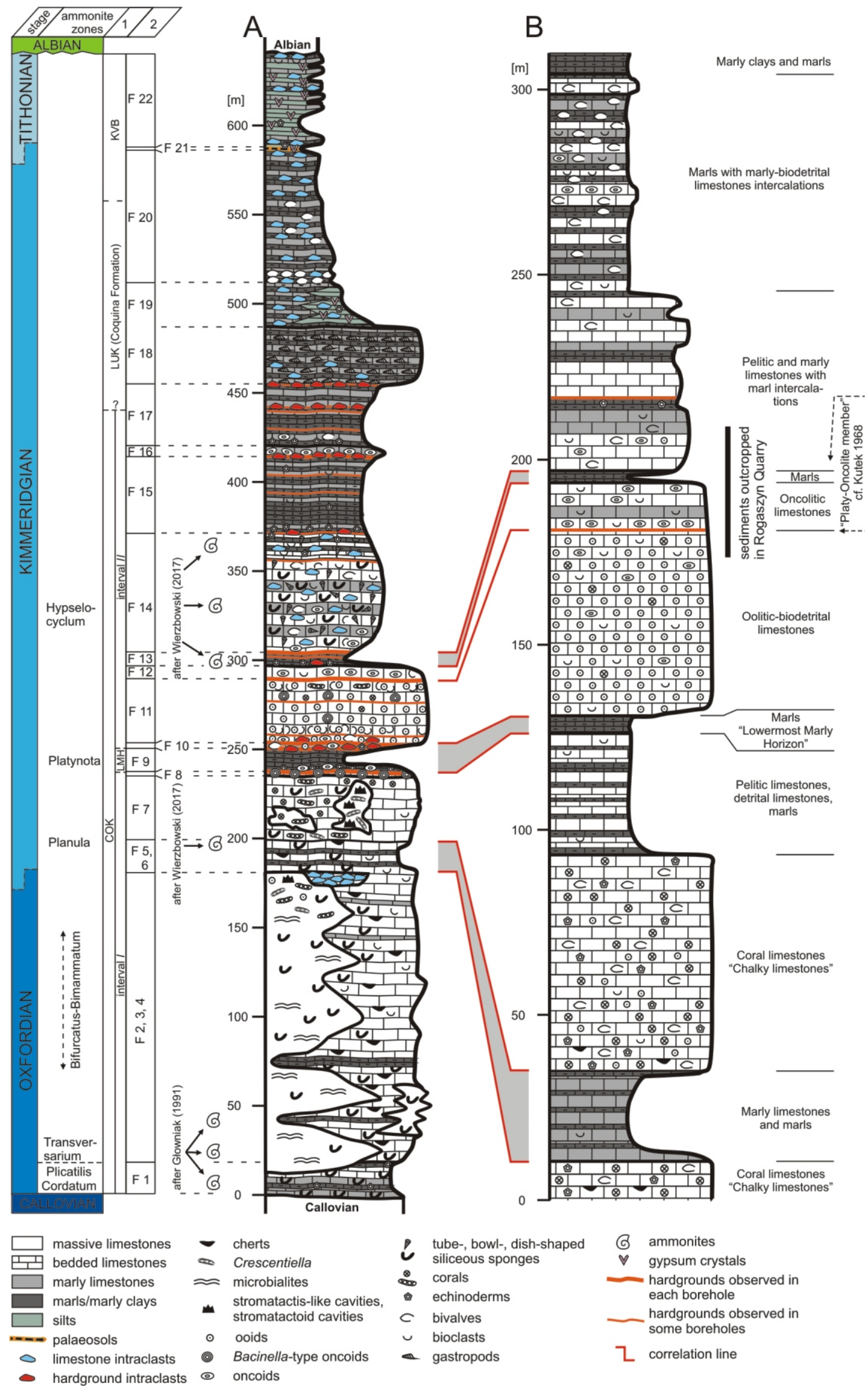

Fig. 12. Correlation of lithologic columns from the Szczerców area (A; after Olchowy et al., 2019) and the Kodrąb area (B; modified from Barwicz-Piskorz, 1995)

1 - tectono-stratigraphic units after Kutek (1994): COK Sequence - Callovian, Oxfordian and Lower Kimmeridgian, LUK Sequence - Lower and Upper Kimmeridgian, KVB Sequence - topmost Kimmeridgian, Volgian and Lower Berriasian, LMH - Lowermost Marly Horizon; 2 - facies in the sedimentary succession of the Szczerców area 
szyn Quarry thus corresponds to both the upper part of the oolitic lithological unit found in the adjacent Szczerców area (Olchowy et al., 2019) and to the "Upper Oolite" of the SW margin of the Holy Cross Mts. (Kutek, 1968; Alexandrowicz and Barwicz-Piskorz, 1974; Matyja, 2011). In Rogaszyn area, the oolitic-biodetrital limestones reach a thickness of up to $50 \mathrm{~m}$ and contain bivalves, gastropods, individual corals and oncoids in their upper part. The oolitic limestones (FT 1) are separated from the overlying oncolitic limestones (FT 2, up to $12 \mathrm{~m}$ thick; Barwicz-Piskorz, 1992, 1995) by a characteristic regional hardground, which represents a significant correlation horizon as it can be observed all across the central Poland (see e.g., Kaźmierczak and Pszczółkowski, 1968; Gruszczyński, 1986; Barwicz-Piskorz, 1992, 1995; Kutek et al., 1992; Matyja, 2011; Krajewski et al., 2014, 2017; Olchowy et al., 2019). On the neighbouring SW margin of the Holy Cross Mts., the oolitic facies is overlain by the "Oncolitic Horizon", up to $2 \mathrm{~m}$ thick (e.g. Kutek and Radwański, 1965; Kutek, 1968; Matyja, 2011), showing a bipartite development (Kutek and Radwański, 1967: 268). The lower part of this horizon, $\sim 30-40 \mathrm{~cm}$ thick, is dominated by densely packed macro-oncoids, which may correspond to the FT 2 facies, but in its upper part, both the number and the size of oncoids decrease (see also Kutek and Radwański, 1967), similarly to the FT 3 facies. These facies also occur in the Szczerców area (Krajewski et al., 2014; F 12 facies after Olchowy et al., 2019; Fig. 12A). The oncolitic limestones grade upwards into marls, several metres thick (Barwicz-Piskorz, 1992, 1995; Fig. 12B). These marls may be compared to the $7.5 \mathrm{~m}$ thick marls deposited above the oncolitic facies in the Szczerców area (F 13 facies after Olchowy et al., 2019; Fig. 12A) and to the "Oolite-Platy Member" known from the SW margin of the Holy Cross Mts. (Matyja, 2011). When correlating the succession from the Kodrab area with these lithostratigraphic units, Barwicz Piskorz $(1992,1995)$ included the "Platy-Oncolite member" after Kutek (1968: 527) within the "Oolite-Platy member" sensu Kutek (1968). These are overlain by pelitic (in places also oolitic) and marly limestones with marl intercalations, of a total thickness of up to $23 \mathrm{~m}$ (Barwicz-Piskorz, 1992, 1995; Fig. 12B). These are the youngest sediments observed in Rogaszyn Quarry. In that interval of the Rogaszyn succession, the lithology of the Upper Jurassic sediments differs from those of the Szczerców area, where sponge-bivalve-oncolitic limestones and marly limestones, up to $75 \mathrm{~m}$ thick, occur (F 14 facies after Olchowy et al., 2019: Fig. 12A). In the Kodrąb area, the pelitic and marly limestones with marl intercalations are overlain by $14 \mathrm{~m}$ of platy pelitic limestones and marly limestones with numerous oysters, intercalated with marls (Hypselocyclum Zone after Barwicz-Piskorz, 1992), followed by $10 \mathrm{~m}$ of marls with abundant bivalves and some ooids overlain by $64 \mathrm{~m}$ of marls and oyster coquinas with mass accumulations of Nanogyra virgula and $N$. nana, which are locally intercalated by marly-biodetrital limestones (Fig. 12B). Although not all these deposits contain sponges (see Barwicz-Piskorz, 1992, 1995), it seems that they may well correspond to the $\mathrm{F} 14$ facies distinguished by Olchowy et al (2019). According to Barwicz-Piskorz (1992, 1995), unlike the underlying strata, the youngest deposits in the Kodrąb succession do not contain fossils and are developed as marly clays and platy marls up to $\sim 6 \mathrm{~m}$ thick. Similar deposits were described in the Szczerców area, where the $F 14$ facies is overlain by marls and marly limestones with very scarce bioclasts categorized as the F 15 facies (Fig. 12A).

\section{CONCLUSIONS}

The Upper Jurassic succession in Rogaszyn Quarry (central Poland) comprises six Lower Kimmeridgian facies types (FT 1 to FT 6), which correspond to coated-grain-dominated carbonate, pelitic and carbonate-siliciclastic deposits representing shallow-water, open-marine/restricted lagoon, shoal and back-shoal environments of an inner carbonate ramp. Numerous coated grain types were identified in these deposits, with ooids and oncoids as dominant components and less common aggregate grains and cortoids. Regarding the ooids, radial-fibrous, micritic and mixed, micritic-radial-fibrous varieties were distinguished. For oncoids, three types were defined based on the composition of their cortices. Type 1 oncoids have micritic, non-laminated or micritic, laminated cortices. Type 2 oncoids show laminated, fossil-bearing cortices surrounded by microbial envelopes. Type 3 oncoids are represented by Bacinella-dominated meshworks incorporating smaller ooids, oncoids and bioclasts, or have complex cortices with micritic and laminated, fossil-bearing Bacinella-dominated fabric overgrown by microbial envelopes. Contacts of particular types of envelopes are usually sharp, with faunal encrustations, bivalves and borings, which reveals time breaks during growth of the oncoids. Common are Entobia isp. chambers and Troglotella incrustans. The complex cortices of the oncoids document various growth stages controlled by relatively short-duration changes in sea level, wave/current energy and microbial activity.

The facies types described, integrated with data from continuous borehole cores, have enabled better characterization of the Upper Jurassic sedimentary succession of the Smotryszów Anticline of the Radomsko Folds. The strata of the Smotryszów Anticline can be lithostratigraphically correlated with the Lower Kimmeridgian deposits of the adjacent Szczerców area and the SW margin of the Holy Cross Mts. In these regions, coral limestones, marly and pelitic limestones, marls, oolitic and oncolitic limestones occupy similar positions in the sedimentary successions. According to the traditional litostratigraphic subdivision of central Poland after Dembowska (1979), these deposits belong to the "Coral" and "Oolitic" formations, and comprise a number of local lithostratigraphic subdivisions. The marl horizon located between the coral and the oolitic facies represents the "Lowermost Marly Horizon", important for regional correlation in both central and southern Poland. The sedimentary succession encountered in Rogaszyn Quarry corresponds to the upper part of the oolitic unit described in the adjacent Szczerców area or to the upper part of the "Upper Oolite" known from the SW margin of the Holy Cross Mts. In all the areas mentioned above, a characteristic, trans-regional hardground which separates oolitic limestones (FT 1 facies in this paper) from oncolitic limestones (FT 2 facies in this paper) is observed. The oncolitic facies of Rogaszyn Quarry in turn represents the "Platy Oncolite member" after Kutek (1968).

Acknowledgements. The authors are very much indebted to the reviewers, A. Strasser, C. Sequero and anonymous reviewer for their very carefull and detailed reviews, constcructive comments and suggestions that considerably improved this paper. We are also grateful to the staff of Rogaszyn Quarry who kindly enabled fieldwork in the quarry. The research was financed from the AGH-UST Grant no. 16.16.140.315. 


\section{REFERENCES}

Alexandrowicz, S.W., Barwicz-Piskorz, W., 1974. Profile stratygraficzne górnej jury w obrzeżeniu Gór Świętokrzyskich. Cz. III - Góra Bukowa w Skórkowie koło Małogoszczy. Zeszyty Naukowe AGH, Geologia, 19: 71-86.

Barwicz-Piskorz, W., 1992. Microfauna of the Upper Oxfordian and Lower Kimmeridgian sediments in the vicinity of Kodrąb (Central Poland) (in Polish with English summary). Geologia-Kwartalnik Akademii Górniczo-Hutniczej im. St. Staszica w Krakowie, 18: 95-115.

Barwicz-Piskorz, W., 1995. Foraminiferal assemblages and stratigraphy of Upper Jurassic in Holy Cross Mountains district (in Polish with English summary). Dissertations Monographies, 21.

Bádenas, B., Aurell, M., 2010. Facies models of a shallow-water carbonate ramp based on distribution of non-skeletal grains (Kimmeridgian, Spain). Facies, 56: 89-110.

Chudzikiewicz, L., Wieczorek, J., 1985. Bored and encrusted clasts in the Lower Kimmeridgian carbonates at Sobków (SW margin of the Holy Cross Mts., Poland). Annales Societatis Geologorum Poloniae, 55: 295-306.

Colombié, C., Schnyder, J., Carcel, D., 2012. Shallow-water marl-limestone alternations in the Late Jurassic of western France: cycles, storm event deposits or both? Sedimentary Geology, 271-272: 28-43.

Dadlez, R., Marek, S., Pokorski, J., 2000. Geological map of Poland without Cainozoic deposits, scale 1:1 000 000. Państwowy Instytut Geologiczny, Warszawa.

Dembowska, J., 1979. Systematization of lithostratigraphy of the Upper Jurassic in northern and central Poland (in Polish with English summary). Kwartalnik Geologiczny, 23 (3): 617-630.

Dupraz, C., Strasser, A., 1999. Microbialites and micro-encrusters in shallow coral bioherms (Middle to Late Oxfordian, Swiss Jura Mountains). Facies, 40: 101-130.

Einsele, G., Ricken, W., 1991. Larger cycles and sequences: introductory remarks. In: Cycles and Events in Stratigraphy (eds. G. Einsele, W. Ricken and A. Seilacher): 611-616. Springer, Berlin.

Flügel, E., 2004. Microfacies of Carbonate Rocks, Analysis, Interpretation and Application. Springer, Berlin.

Fürsich, F.T., Oschmann, W., 1986. Storm shell beds of Nanogyra virgula in the upper Jurassic of France. Neues Jahrbuch für Geologie und Paläontologie Abhandlungen, 172: 141-161.

Gąsiewicz, A., 1984. Upper Jurassic ooids with eccenrical covers (in Polish with English summary). Kwartalnik Geologiczny, 28 (1): 93-106.

Głowniak, E., 1991. Utwory keloweju i oksfordu w odkrywce Bełchatów (in Polish with English summary). Przegląd Geologiczny, 39: 79-84.

Goldring, R., Kaźmierczak, J., 1974. Ecological succession in intraformational hardground formation. Palaeontology, 17: 949-962.

Gruszczyński, M., 1986. Hardgrounds and ecological succession in the light of early diagenesis (Jurassic, Holy Cross Mts., Poland). Acta Palaeontologica Polonica, 31: 163-212.

Jaworowski, K., 1962. Jura w zachodniej części rygla przedborskiego (in Polish). Przegląd Geologiczny, 10: 46-47.

Karczewski, L., 1965. Fauna and stratigraphy of the Malm in the vicinity of Radomsko (Central Poland) (in Polish with English summary). Biuletyn Instytutu Geologicznego, 192: 97-146.

Kästner, M., Schülke, I., Winsemann, J., 2008. Facies architecture of a Late Jurassic carbonate ramp: the Korallenoolith of the Lower Saxony Basin. International Journal of Earth Sciences, 97: 991-1011.

Kaźmierczak, J., Pszczółkowski A., 1968. Sedimentary discontinuites in the Lower Kimmeridgian of the Holy Cross Mts. (in Polish with English summary). Acta Geologica Polonica, 28: 587-616.

Krajewski, M., Olchowy, P., Felisiak, I., 2014. Lower Kimmeridgian layer with bored and encrusted hiatus concretions (Upper Jurassic, Central Poland): implications for stratig- raphy and basin evolution. Annales Societatis Geologorum Poloniae, 84: 113-129.

Krajewski, M., Olchowy, P., Zatoń, M., Bajda, T., 2017. Kimmeridgian hardground-sequence boundary from the Mesozoic margin of the Holy Cross Mountains (central Poland): implications for the evolution of the northern Tethyan carbonate shelf. Facies, 63: 15.

Krajewski, M., Olchowy, P., Rudziński D., 2018. Sedimentary successions in the Middle-Upper Oxfordian reef complex from the Kraków-Częstochowa Upland (Southern Poland). Geological Quarterly, 62 (3): 653-668.

Krajewski, M., Olchowy, P., Salamon, M.A., 2019. Late Jurassic (Kimmeridgian) sea lilies (Crinoidea) from central Poland (Łódź Depression). Annales de Paléontologie, 105: 63-73.

Kutek, J., 1968. The Kimmeridgian and Uppermost Oxfordian in the SW margins of the Holy Cross Mts. (Central Poland); Part I Stratigraphy (in Polish with English summary). Acta Geologica Polonica, 18: 493-587.

Kutek, J., 1994. Jurassic tectonic events in south-eastern Poland. Acta Geologica Polonica, 44: 167-221.

Kutek, J., Radwański, A., 1965. Upper Jurassic onkolites of the Holy Cross Mts. (Central Poland). Bulletin de l'Academie Polonaise des Sciences, 13: 155-160.

Kutek, J., Radwański, A., 1967. Sedimentological problems of Lower Kimmeridgian onkolitic horizon at Celiny in the Holy Cross Mts (in Polish with English summary). Rocznik Polskiego Towarzystwa Geologicznego, 37: 267-272.

Kutek, J., Matyja, B.A., Wierzbowski, A., 1992. The Holy Cross Mountains - introduction. In: Oxfordian \& Kimmeridgian joint working groups meeting (eds. B.A. Matyja, A. Wierzbowski and A. Radwański): 22-26. International Subcommision on Jurassic Stratigraphy, Warszawa.

Łuniewski, A., 1947. Notes on geology in the vicinity of Radomsko (in Polish with English summary). Biuletyn Państwowego Instytutu Geologicznego, 38: 9-21.

Machalski, M., 1998. Oyster life positions and shell beds from the Upper Jurassic of Poland. Acta Palaeontologica Polonica, 43: 609-634.

Matyja, B.A., 2011. Płytkowodna platforma węglanowa późnej jury na południowo-zachodnim obrzeżeniu Gór Świętokrzyskich materiały do sesji terenowych. Materiały Konferencyjne Jurassica IX, Małogoszcz, 06-08 września 2011 (in Polish). In: Polskie Towarzystwo Geologiczne, Polska Grupa Robocza Systemu Jurajskiego: 133-151.

Matyja, B.A., Gutowski, J., Wierzbowski, A., 1989. The open shelf-carbonate platform succession at the Oxfordian/Kimmeridgian boundary in the SW margin of the Holy Cross Mts: stratigraphy, facies and ecological implications. Acta Geologica Polonica, 39: 29-48.

Matyszkiewicz, J., 1997. Microfacies, sedimentation and some aspects of diagenesis of Upper Jurassic sediments from the elevated part of the Northern peri-Tethyan Shelf: a comparative study on the Lochen area (Schwäbische Alb) and the Cracow area (Cracow-Wielun Upland, Poland). Berliner Geowissenschaftliche Abhandlungen, E21: 1-111.

Matyszkiewicz, J., Kochman, A., 2016. Pressure dissolution features in Oxfordian microbial-sponge buildups with pseudonodular texture, Kraków Upland, Poland. Annales Societatis Geologorum Poloniae, 86: 355-377.

Matyszkiewicz, J., Kochman, A., Duś, A., 2012. Influence of local sedimentary conditions on development of microbialites in the Oxfordian carbonate buildups from the southern part of the Kraków-Częstochowa Upland (south Poland). Sedimentary Geology, 263-264: 109-132.

Mrozek, K., 1975. Budowa geologiczna struktur wgłębnych w południowej części synklinorium łódzkiego (in Polish). Wyd. Geol., Warszawa. 
Munnecke, A., Samtleben, C., 1996. The formation of micritic limestones and the development of limestone-marl alterations in the Silurian of Gotland, Sweden. Facies, 34: 159-176.

Munnecke, A., Westphal, H., Reijmer, J.J.G., Samtleben, C., 1997. Microspar development during early marine burial diagenesis: a comparison of Pliocene carbonates from the $\mathrm{Ba}-$ hamas with Silurian limestones from Gotland (Sweden). Sedimentology, 44: 977-990.

Myrow, P.M., Fischer, W., Goodge, J.W., 2002. Wave-modified turbidites: combined-flow shoreline and shelf deposits, Cambrian, Antarctica. Journal of Sedimentary Research, 72 641-656.

Olchowy, P., Krajewski, M., 2019. The Early Kimmeridgian succession at Kodrąb (Radomsko elevation, central Poland) and its palaeogeographical and palaeotectonic implications - discussion. Geological Quarterly, 63 (1): 209-211.

Olchowy, P., Krajewski, M., Felisiak, I., 2019. Late Jurassic facies succession of the Kleszczów Graben area (southern border of the Łódź Depression, peri-Tethyan shelf, central Poland). Geological Quarterly, 63 (4): 657-682.

Peryt, T.M., 1983. Classification of coated grains. In: Coated Grains (ed. T.M. Peryt): 3-6. Springer, Berlin

Pożaryski, W., 1974. Budowa geologiczna Polski, IV, Tektonika, cz. 1, Niż Polski. Wyd. Geol., Warszawa.

Pożaryski, W., Brochwicz-Lewiński, W., Brodowicz, Z. Jaśkowiak-Schoeneichowa, M., Milewicz, J., Sawicki, L., Uberna, T., 1979. Geological map of Poland and adjoining countries without Cenozoic formations 1:1 000000 (in Polish). Geological Institiute, Warszawa.

Roniewicz, E., Roniewicz, P., 1971. Upper Jurassic coral assemblages of the Central Polish Uplands. Acta Geologica Polonica, 21: $399-424$

Schlagintweit, F., 2010. Taxonomic revision of Lithocodium aggregatum ELLIOTT sensu Schmid \& Leinfelder, 1996 Jahrbuch der Geologischen Bundesanstalt, 156: 393-406.

Sequero, C., Aurell, M., Bádenas, B., 2020. Oncoid distribution in the shallow domains of a Kimmeridgian carbonate ramp (Late Jurassic, NE Spain). Sedimentary Geology, 398: 1-20.

Słonka, Ł., Krzywiec, P., 2020a. Upper Jurassic carbonate buildups in the Miechów Trough, Southern Poland - insights from seismic data interpretation. Solid Earth, 11: 1097-1119.

Słonka, Ł., Krzywiec, P., 2020b. Seismic characteristics and development of the Upper Jurassic carbonate buildups from the Miechów Trough (Southern Poland). Geosciences, 10: 239.

Strasser, A., 1986. Ooids in Purbeck limestones (lowermost Cretaceous) of the Swiss and French Jura. Sedimentology, 33: $711-727$.
Strasser, A., Védrine, S., Stienne, N., 2012. Rate and synchronicity of environmental changes on a shallow carbonate platform (Late Oxfordian, Swiss Jura Mountains). Sedimentology, 59: 185-211.

Trammer, J., 1989. Middle to Upper Oxfordian sponges of the Polish Jura. Acta Geologica Polonica, 39: 49-91.

Tucker, M.E., Wright, V.P., 1990. Carbonate Sedimentology. Wiley-Blackwell, Oxford.

Védrine, S., Strasser, A., Hug, W., 2007. Oncoid growth and distribution controlled by sea-level fluctuations and climate (Late Oxfordian, Swiss Jura Mountains). Facies, 53: 535-552.

Westphal, H., Munnecke, A., Brandano, M., 2008. Effects of diagenesis on the astrochronological approach of defining stratigraphic boundaries in calcareous rhythmites: the Tortonian GSSP. Lethaia, 41: 461-476.

Westphal, H., Hilgen, F., Munnecke, A., 2010. An assessment of the suitability of individual rhythmic carbonate succession for astrochronological application. Earth-Science Reviews, 99: 33-59.

Wierzbowski, A., 2017. The Lower Kimmeridgian of the Wieluń Upland and adjoining regions in central Poland: lithostratigraphy, ammonite stratigraphy (Upper Planula/Platynota to Divisum zones), palaeogeography and climate-controlled cycles. Volumina Jurassica, 15: 1-80.

Wierzbowski, A., Głowniak, E., 2018. The Early Kimmeridgian succession at Kodrab (Radomsko elevation, central Poland) and its palaeogeographical and palaeotectonic implications. Geological Quarterly, 62 (3): 509-521.

Wierzbowski, A., Głowniak, E., 2019. The Early Kimmeridgian succession at Kodrąb (Radomsko elevation, central Poland) and its palaeogeographical and palaeotectonic implications reply. Geological Quarterly, 63 (1): 212-214.

Zatoń, M., Machalski, M., 2013. Oyster-microbial rolling stones from the Upper Jurassic (Kimmeridgian) of Poland. Palaios, 28 839-850.

Ziegler, P.A., 1990. Geological Atlas of Western and Central Europe. Shell Internationale Petroleum Maatschappij B.V.

Zuo, F., Heimhofer, U., Huck, S., Luppold, F.W., Wings, O., Erbacher, J., 2018. Sedimentology and depositional sequences of a Kimmeridgian carbonate ramp system, Lower Saxony Basin, Northern Germany. Facies, 64: 1.

Żelaźniewicz, A., Aleksandrowski, P., Buła, Z., Karnkowski, P.H., Konon, A., Oszczypko, N., Ślączka, A., Żaba, J, Żytko, K., 2011. Regionalizacja tektoniczna Polski (in Polish). Komitet Nauk Geologicznych PAN, Wrocław. 